\title{
Inequality and Happiness: Are Europeans and Americans Different?
}

\section{Citation}

Alesina, Alberto, Rafael Di Tella, and Robert MacCulloch. 2004. Inequality and happiness: Are Europeans and Americans different? Journal of Public Economics 88(9-10): 2009-2042.

\section{Published Version}

doi:10.1016/j.jpubeco.2003.07.006

\section{Permanent link}

http://nrs.harvard.edu/urn-3:HUL.InstRepos:4553007

\section{Terms of Use}

This article was downloaded from Harvard University's DASH repository, and is made available under the terms and conditions applicable to Other Posted Material, as set forth at http:// nrs.harvard.edu/urn-3:HUL.InstRepos:dash.current.terms-of-use\#LAA

\section{Share Your Story}

The Harvard community has made this article openly available.

Please share how this access benefits you. Submit a story.

Accessibility 


\title{
Inequality and Happiness: Are Europeans and Americans Different?*
}

\author{
Alberto Alesina \\ Rafael Di Tella \\ Harvard University, \\ NBER and CEPR \\ Harvard Business School
}

Robert MacCulloch

London School of Economics

First draft: December 2000

This draft: June 2002

\begin{abstract}
*We thank Eliana La Ferrara, Norman Loayza, Andrew Oswald, Thomas Piketty, three anonymous referees and participants in many seminars for discussions and comments. We are very grateful to thank Rebecca Blank, Eliana La Ferrara, Jeff Perloff and Ximing Wu for generous help with data. Min Shi provided excellent research assistance. Alesina gratefully acknowledges financial support form the NSF through the NBER.
\end{abstract}




\title{
Inequality and Happiness: Are Europeans and Americans Different?
}

\begin{abstract}
We study the effect of the level of inequality in society on individual well being using a total of 123,668 answers to a survey question about "happiness". We find that individuals have a lower tendency to report themselves happy when inequality is high, even after controlling for individual income, a large set of personal characteristics, and year and country (or, in the case of the US, state) dummies. The effect, however, appears to be stronger in Europe than in the US. In addition we find a striking difference across groups. In Europe, the poor and those on the left of the political spectrum are unhappy about inequality; whereas in the US the happiness of the poor and of those on the left is uncorrelated with inequality. Interestingly, in the US it is the rich who are especially bothered by inequality. We argue that these findings are consistent with the perception (not necessarily the reality) that Americans have of living in a mobile society, where individual effort can move people up and down the income ladder, while Europeans believe that they live in less mobile societies.
\end{abstract}

Alberto Alesina

Harvard University,

NBER and CEPR
Rafael Di Tella

Harvard Business School
Robert MacCulloch

London School of Economics 


\section{Introduction}

Most governments redistribute income, using both direct and indirect means. Even though this role of the public sector has increased vastly in the last few decades in all industrial countries, European governments are more heavily involved with redistribution than that of the United States. European fiscal systems are more progressive than in the United States and the welfare state is more generous in Europe, where the share of government in the economy is substantially larger than in the United States. For instance, in 1996 the share of total government spending (excluding interest payments) over GDP was about 30 percent in the US, versus 44 percent in Europe. The share of transfers over GDP was about 14 percent in the US and about 22 percent in Europe. ${ }^{1}$ At the end of the nineteenth century, the share of transfers over GDP was less than 1 percent both in Europe and the US. It was about 6 percent of GDP in the US, and about 10 percent of GDP in Europe in 1960. The growth of transfers explains almost all of the increase in the size of government and the difference in the size of government between Europe and the US.

If democratic governments redistribute so much, it must mean that a large fraction of the population favors these programs. For a start, the "poor" should be in favor of redistribution, since they gain from it on net. However, this preference is mitigated by the fact that the poor of today may become the rich of tomorrow and they do not want to be the ones who will have to support redistributive schemes. Conversely the rich should oppose redistributions, but if they fear to become poor they may see redistributive policies as an insurance against future potential misfortunes. Therefore, social mobility should influence how forward looking individuals value redistributive polices. ${ }^{2}$

Beyond self-interest, however, inequality (which is often associated with high poverty rates) may be perceived as a social evil. That is, at least up to a point, even the net losers from redistributive schemes may favor them because they perceive poverty and inequality as social harms. In part this may also be motivated indirectly by self-interest, to the extent that inequality breeds crime and threats to property rights. But, even beyond that, the observation (or perception) of poverty may negatively affect the welfare of the rich and their sense of fairness.

\footnotetext{
${ }^{1}$ For historical data on the growth of redistributive programs in industrial countries, see Tanzi and Schuknecht (2000). For a comparison of redistributive policies in the US and in Europe see Alesina, Glaeser and Sacerdote (2001)

${ }^{2}$ See Benabou and Ok (2000) for a precise theoretical formulation of this idea and Alesina and La Ferrara (2000) for empirical tests.
} 
In this paper, we explore whether and why inequality negatively affects individual utility even after controlling for individual income. We measure "utility" in terms of survey answers about "happiness." Some readers may feel uncomfortable using such a vague question like "are you happy?" for any useful statistical investigation. As we discuss below, however, a growing literature both in psychology and in economics successfully uses it, and the patterns observed in the answers to this question are reasonable and quite similar across countries. This gives us confidence in the significance of using such data to study inequality.

We find some intriguing results. First, Europeans seem to dislike inequality more than Americans. ${ }^{3}$ Second, aversion to inequality is concentrated amongst different ideological and income groups across the two regions. There is no clear ideological divide in the US concerning the effect of inequality on happiness. In contrast, those who define themselves leftist show a strong distaste for inequality in Europe, while those who define themselves rightists are unaffected by it. More interestingly the breakdown of rich versus poor shows large differences between Europe and the US. In Europe, the happiness of the poor is strongly negatively affected by inequality, while the effect on the rich is weaker and statistically insignificant. In the US one finds the opposite pattern, namely that the group whose happiness seems to be most adversely affected by inequality is the rich. A striking result is that the US poor seem totally unaffected by inequality. Any significance of the inequality coefficient in the US population is mainly driven by the rich.

We argue that these results are due to different perceptions of the degree of social mobility in the US and Europe. Americans believe that their society is mobile so the poor feel that they can move up and the rich fear falling behind. In Europe a perception of a more immobile society makes the poor dislike inequality since they feel "stuck".

Given that European citizens seem so averse to inequality, they should favor redistributive policies, i.e. the welfare state. Broadly speaking this is the message of Boeri, Borsch-Syupan and Tabellini (2000). In a survey conducted in three European countries they find that Germans, Italians and

\footnotetext{
${ }^{3}$ Given the lack of an established source in the literature, we experimented with different inequality data for the US. The data we use in this version of the paper are probably the most accurate. However it is worth mentioning that with other data the effect of inequality on well-being in the US is even weaker and not statistically significant. For more discussion of this point see the working paper version of this article.
} 
Spaniards are reluctant to favor cuts in welfare programs, even though they show a lack of clear understanding of the costs associated with them namely, they tend to understate the costs. Di Tella and MacCulloch (1996) find a desire for higher unemployment benefits in 5 out of 6 European countries (the exception being Norway) and a desire for lower or equal unemployment benefits in the United States and Australia.

The present paper is at the crossroads of two lines of research. One is the study of the determinants of "happiness". The economic literature started with Easterlin (1974), who documented stagnant average happiness levels in the US in the face of large increases in income, a question recently taken up by Blanchflower and Oswald (2000) and Inglehart (1996). ${ }^{4}$ A number of subsequent papers have focused on micro economic aspects; including the role of being unemployed on self reported well being (Clark and Oswald (1994), Winkelman and Winkelman (1991)). Di Tella, MacCulloch and Oswald (1997) show that the country-level "micro happiness" regressions display a very similar structure across 12 OECD countries. That paper also takes a macro perspective by including aggregate unemployment and a measure of the generosity of the welfare state in these happiness regressions. Other work has used happiness data to study the role of democratic institutions (Granato, Inglehart and Leblang (1996) and Frey and Stutzer (1999)), the inflation-unemployment trade-off (Di Tella, MacCulloch and Oswald (1999)), partisan versus opportunistic models (Di Tella and MacCulloch (1998)) and the role of social norms (Stutzer and Lalive (2000)). An early paper by Morawetz et al (1973) discusses how average happiness varies across two communities in Israel that have different levels of inequality. ${ }^{5}$

The second line of research is the literature on the determinants of preferences for redistribution. On the theoretical side some of the key papers are Romer (1977) and Meltzer and Richards (1981) on inequality and redistributions, and Piketty (1995) and Benabou and Ok (2000) on social mobility. Recent empirical work on the demand for redistribution includes Alesina and La Ferrara (2000), Ravallion and Loshkin (2000), Corneo (2000) and Corneo and Gruner (2000). These papers find,

\footnotetext{
4 There is, to be sure, a large literature in psychology using self reported measures of well being (see Diener, Suh, Lucas and Smith (1999) and Kahneman, Diener and Schwartz (1999)).

${ }^{5}$ Our paper, and we believe much of the happiness literature, can be understood as an application of experienced utility, a concept that emphasises the pleasures derived from consumption (discussed in Kahneman and Thaler (1991)). It argues, in essence, that there are circumstances where measures of experienced utility can be derived (such as happiness responses) that are reasonable substitutes to observing individual choices. $\mathrm{Ng}$ (1996) discusses the theoretical structure of subjective well-being responses while Kahneman, Wakker and Sarin (1997) propose a formal axiomatic defense of experienced utility (see also Tinbergen (1991) and van Praag (1991)).
} 
looking at the data from the US, Europe and in one case, Russia, that social mobility does affect the preference for redistribution.

This paper is organized as follows. Section 2 describes our data set. Section 3 presents results for the US. Section 4 present results for European countries. In Section 5 we compare results for the US and Europe. The last section concludes.

\section{Data and Empirical Strategy}

\subsection{Description}

The analysis examines U.S. happiness data from the United States General Social Survey (19721997). We use the happiness question that reads "Taken all together, how would you say things are these days - would you say that you are very happy, pretty bappy, or not too happy?" (Small "Don't know" and "No answer" categories are not studied here). This was asked in each of 25 years. In the main analysis, data limitations on state-level inequality data force us to restrict attention to the 19,895 answers that are available for the period 1981-96.

For Europe, the source of happiness data is the Euro-Barometer Survey Series (1975-1992), which interviews a random sample of Europeans in each year and asked two questions, among others, that interest us. The first is "Taking all things together, how would you say things are these days - would you say you're very happy, fairly happy, or not too happy these days?" (small "Don't know" and "No answer" categories are not studied here). The surveys also report the answers of a large number of individuals over 18 years of age to a "life satisfaction" question. This question is included because the word "happy" translates imprecisely across languages. This question is: "On the whole, are you very satisfied, fairly satisfied, not very satisfied or not at all satisfied with the life you lead?" (The small "Don't know" and "No answer" categories are not studied here). We focus on life satisfaction data because they are available for a longer period of time - from 1975 to 1992 instead of just 1975-86. "Happiness" and "life satisfaction" are highly correlated.

Because we are interested in comparing our results for Europe with those for the US, we coded the European data into similar categories. Since we have three categories for the US and four for 
Europe, we collapsed European responses that fell into the two bottom categories (not very satisfied and not at all satisfied) into one. In any case, very similar results obtain when the four categories are used for Europe. Appendix 1 describes both the U.S. General Social Survey and the EuroBarometer Survey Series in greater detail.

For the United States, we take Gini coefficients of per state per year for the period 1981-96 from Wu, Perloff and Golan (2002). They use income data from the Current Population Survey (CPS) March Supplement. Beginning in 1981, the CPS includes information on the value of government transfers, tax liability and credit for each family. Wu, Perloff and Golan then collect data from the American Housing Survey, the Income Survey Development Program and the Internal Revenue Service and combine them with the CPS data to create simulations of taxes paid, number of tax filing units, adjusted gross income, and other characteristics for the March CPS. Based on the augmented series, the authors construct the after-transfer, after-tax monetary income by adding the CPS income with the corresponding value of food stamps, tax payments or credits for each family. Based on these data they create what to our knowledge is one of the best series of inequality measures at the state level for the US that we have available today. For more description of these data, see Wu, Perloff and Golan (2002).

For Europe, we use Gini coefficients from the Deininger and Squire (1996) data set. We use only part of their "high quality" data. These data satisfy three minimum standards of quality: they are based on household surveys, the population covered is representative of the entire country and the measure of income (or expenditure) used is comprehensive including income from self-employment, non-wage earnings as well as non-monetary income. The data set is normally considered the best available for cross-country comparison and it is widely used. However, it is not without its drawbacks, as discussed by Atkinson and Brandolini (1999). The problems concern the fact that the Gini coefficients for different countries have not all been calculated using the same methods. For example, some are based on gross income, while others use net (disposable) income. In our sample, 3 observations for Denmark, 3 observations for France and 4 observations for Germany are based on gross income whereas the rest are based on net income. In addition, although the Deininger and Squire (1996) data set is largely based on the household as the choice of reference unit, some measurements are based at the individual level. Another difference between the country time series of Gini coefficients is that some use expenditure whereas others use income. In order to minimise 
problems caused by the differences in definitions and sources, we use only consistent time series of their "high quality" data within each country. The remaining differences in the bases used to estimate inequality across countries are at least partially controlled for by including country dummies. The definitions and sources of other variables used in the paper are described in Appendix 1.

Tables A-US, B-US, A-Eur and B-Eur report some basic statistics for our US and European samples. Concerning "happiness," the patterns across Europe and the US seem similar, which is somewhat reassuring that the question is interpreted similarly in the two places. For a start, the breakdown between different levels of happiness in the sample is fairly similar in Europe and the US. For instance, about 57 per cent in the US and 54 per cent in Europe are in the intermediate category. Patterns of happiness and marital status are similar. Interestingly, personal income seems to have a stronger effect in the US than in Europe, an observation consistent with a larger share of public consumption and more progressive taxation in Europe than in the US.

\subsection{Discussion of "happiness data"}

Many readers may worry about using answers to questions like "are you happy?” for any rigorous statistical work. While a healthy dose of scepticism is always useful, there are good reasons why these "happiness" data should not be dismissed. Here, we review some of the arguments made in the previous literature in favour of using happiness data.

The first reason is based on the fact that psychologists, who study well being for a living, widely use these data. Presumably, people who insist on using bad data would be driven out of the market. A second argument is that well-being data pass what psychologists often call validation exercises. Happiness responses are correlated with physical reactions that can be thought of as describing true, internal happiness. Pavot (1991), and Eckman, Davidson and Friesen (1990), for example, find that individuals reporting to be very happy tend to smile more. Shedler, Mayman and Manis (1993) show that happiness data are negatively correlated with heart rate and blood pressure measures of responses to stress. Sutton and Davidson (1997) show that happiness data are positively correlated with electroencephalogram measures of prefrontal brain activity (the part of the brain that is "responsible" for happiness). Other studies include Fordyce (1988), who shows that the different measures of well-being correlate well with one another, Seidlitz, Wyer and Diener (1997) who show that happiness data are correlated with subject recall of positive life events; Diener (1984) and 
Sandvik, Diener and Seidlitz (1993) who show the data are correlated with reports of friends and family members. Konow and Early (1999) discuss a number of studies that are helpful in assessing the validity of well-being data.

The psychology literature has also considered the possibility that subjects are influenced by what they believe to be the socially desirable response when they answer surveys. If the social norm is to be happy, subjects may bias their response upwards. Since the first studies in the area, psychologists have found evidence pointing out that this concern may be exaggerated (e.g. Rorer (1965), Bradburn (1969)). Konow and Early (1999) present experimental evidence showing that the Marlowe-Crowne measure of social desirability is uncorrelated with happiness data.

An additional argument in defence of subjective well-being data, inspired by results presented in Inglehart (1990), is that happiness data are negatively correlated with suicide rates, as Di Tella et al (1997) show. ${ }^{6}$ The same paper (Di Tella et al. (1997)) also presents micro econometric happiness and life satisfaction regressions for 12 European countries and the US. The interesting finding is that these equations seem to share a similar structure across countries.

\subsection{Empirical Strategy}

We compare US states and European countries, and we relate "happiness" in different US states and European countries to inequality, other macroeconomic variables and several individual characteristics. We take advantage of cross-state (or cross-country) and time series variation in inequality and we run similar regressions in the US and Europe, in terms of the definitions of both the left and right-hand side variables, and of specification of the regressions. We run an ordered logit regression of the form

$$
\text { Happy }_{i s t}^{g}=\alpha^{g} \text { Inequality }_{s t}+\beta^{g} M A C R O_{s t}+\delta^{g} M_{\text {ICRO }}+\eta_{s}^{g}+\mu_{t}^{g}+\varepsilon_{i s t}^{g}
$$

where $H_{a p p} y_{i s t}$ is the answer given by individual, $i$, who lives in State, $s$, and year, $t$, to the happiness question “Are you Happy?". In Europe, $s$ refers to countries. The superscript $g$ refers to the fact that we consider the whole sample (in which case $g=$ whole sample), but we also divide it on the basis of 
income (in which case $g=$ rich, $p o o r$ ), or of ideological inclination (in which case $g=$ right, left). The vector $M A C R O_{s t}$ refers to a set of variables aggregated at the State (or country) level that has previously been found to affect individual happiness. These include the inflation rate (Inflation) and the unemployment rate (Unemployment). We also present some checks using the crime rate (Murders). The vector $M I C R O_{i s t}$ refers to a set of personal characteristics of the respondents that have previously been found to affect individual happiness, including age, employment status, income, etc. We also include $\eta_{s}$, a dummy variable for the cross sectional units (State in the US, country in Europe), $\mu_{t}$ a dummy for each year and $\varepsilon_{i s t}$ an error term (i.i.d.). We compute robust standard errors, where we correct for potential heteroscedasticity and for potential correlation of the error term across observations that are contained within a cross sectional unit in any given year (see Moulton (1986)).

\section{Happiness and inequality in the United States}

The period from the early eighties to the mid nineties is characterized by a large and noticeable increase in inequality, particularly in the US. Therefore, this is a rather interesting time period to analyze from our perspective, since there is much variability in the data. All the regressions include state and year dummies.

We begin in column 1 of Table 1-US with a regression that includes only the individual characteristics of the respondent. The results are sensible and provide some confidence in the structure of the responses to the happiness question. First of all, money does bring happiness, as the coefficient on income shows. Even after controlling for income, more educated individuals are happier. On the other hand, being unemployed brings unhappiness, above and beyond an income effect. The results on marital status are consistent with the sociological and medical literature, which show that married individuals live longer and are healthier. The omitted category is "never married," and we find married individuals are happier than unmarried ones; divorced, separated and widowers are less happy then "never married," and, a fortiori, much less happy than married individuals.

\footnotetext{
${ }^{6}$ Inglehart (1990) looks at the cross section. He finds some evidence of a positive correlation and offers some arguments explaining why the correlation may be spurious.
} 
Note that one may argue that there might be a problem of reverse causality: happy and optimistic individuals may be more likely to marry and stay married because they are better at building relationships. We are not interested in precisely establishing causality here. For us, what really matters is that the association between "happiness" and marital status is consistent with evidence drawn from other sources. There is a non-linear effect of age: the least happy decades seem to be the thirties/forties, maybe because the stress of managing professional and personal life is at a peak. Children seem to bring about preoccupations, stress and hard work as the negative coefficients on this variable show. Finally, women seem happier than men, and, not surprisingly, members of a traditionally discriminated minority (blacks) are less happy. All these results seem quite sensible and are consistent with the literature. ${ }^{7}$

In column 2 we add our measure of inequality. The coefficient on inequality is negative and significant at conventional levels. ${ }^{8}$ To simplify the comparisons across columns on macroeconomic variables, we added a number below for each coefficient and standard errors: these numbers are the effect on the probability of moving from one "level" of happiness to the next, as a result of one standard deviation change in the corresponding right hand side variable. Specifically, the number listed below the standard error of each macro variable is the proportion of people who leave (enter) the top happiness category "Very Happy" and consequently enter (leave) one of the bottom two happiness categories, "Pretty Happy" or "Not too Happy", when this is a negative (positive) number. A rise in the Gini of 10 percentage points, equivalent to a rise from the State with the lowest level of (post-tax) inequality in the sample (Wisconsin) to the State with the highest level of inequality (Texas) leads to a fall in the proportion of people reporting themselves as "Very Happy" of 5.8 percentage points and a rise in the proportion reporting themselves as "Not too Happy" of 3.0 percentage points. Since 31.3 per cent of Americans reported themselves as "Very Happy" an increase in inequality of 10 percentage points is expected to bring about an $18.5 \%$ reduction in the amount of people reporting themselves in the top happiness category. Since 11.4 per cent of

\footnotetext{
${ }^{7}$ See Di Tella et. al. (1997) for comparisons of happiness equations across individual OECD countries.

${ }^{8}$ In the working paper version of this paper we found no correlation between inequality and happiness in the US using inequality data (as measured by the Gini coefficient) at the state level from the 1979 and 1989 census. Even when we incorporate the 1969 census the coefficient on inequality in a US happiness regression remains insignificant. We also experimented using state inequality measures (the 80/20 ratio) created by the Economic Policy Institute with Current Population Survey data, averaged for three years every ten years (i.e. 1978-80, 1988-90 and 1998-2000). Again the coefficient on inequality was insignificant in a US happiness regression. Finally, we used a measure of inequality (the 50/10) ratio presented in Blank (2001), calculated from annual wage data from the Outgoing Rotation Group (ORG) data of the monthly CPS, with similarly insignificant results.
} 
Americans reported themselves as "Not too Happy" it would also correspond to a $26 \%$ increase in the number of people reporting themselves in the bottom happiness category. A one standard deviation increase in inequality (equal to 3.2 percentage points) reduces the proportion of people reporting themselves as "Very Happy" by 1.9 percentage points and increases the proportion reporting themselves as "Not too Happy" by 0.9 percentage points.

In the next column (column 3 in Table 1-US) we add an additional macroeconomic variable, the unemployment rate. The implied size of the coefficient on inequality is reduced by almost $27 \%$, and the significance level drops to the 7 percent level. Given the relatively high correlation between inequality and unemployment, equal to 0.14 , this is not too surprising. ${ }^{9}$ Interestingly, the coefficient on unemployment is negative and significant at the 9 percent level, even after we control for personal unemployment status. In other words, unemployment brings unhappiness above and beyond the personal costs of falling unemployed. This is consistent with the effect presented in Di Tella et al (2001), but it is now based on data spanning a 16-year period across 44 states within a single country. A one standard deviation increase in the unemployment rate (equal to 0.023) reduces the proportion of people reporting themselves as "Very Happy" by 1.1 percentage points and increases the proportion reporting themselves as "Not too Happy" by 0.5 percentage points. These figures correspond to a decrease of $3.5 \%$ in the amount of people reporting themselves in the top happiness category (from 31.3 per cent to 30.2 per cent) and an increase of $4.4 \%$ of people selfdeclaring themselves as being "Not too Happy" (from 11.4 per cent to 11.9 per cent).

In column 4 of Table 1-US we add further controls for the level of individual income, namely a dummy that indicates if the respondent's income is in the top half of the state's income distribution. The coefficient on this variable (Top 2 Income Quartiles) is negative and comfortably significant, suggesting that even after controlling for individual income, the relative position of the respondent in terms of the state's income ladder matters. The coefficients on state unemployment and inequality are unaffected.

One of the reasons why inequality may bring unhappiness is because it is correlated with crime. In Appendix 3 we show that these results on inequality do not change even after controlling for crime,

\footnotetext{
9 In a regression of state inequality on state unemployment rates, controlling for country and year fixed effects, the coefficient on the unemployment rate is 0.457 , significant at the 1 per cent level $(\mathrm{t}$-stat $=4.6)$.
} 
measured by auto-theft and murder rates. It turns out that the coefficients on these measures of crime are very imprecisely estimated. Experiments with additional crime data (available upon request) confirm this result. We have chosen not to include crime variables in our basic specification since the best available European crime data had serious consistency problems that made comparisons with the US unfeasible. Various experiments with (imperfect) crime data for the European panels did not change the nature of our results.

In Table 2-US we report the identical regressions of Table 1-US but partitioning the sample across ideological lines. We classified as "left" the respondents that replied 0,1 or 2 to the question “Generally speaking, do you usually think of yourself as a Republican, Democrat, Independent, or what?", where 0 equals "Strong Democrat", 1 equals "Not very strong Democrat" and 2 equals "Independent, close to Democrat". We classified as "right" the respondent that replied 4, 5 or 6, where 4 equals "Independent, close to Republican", 5 equals "Not very strong Republican" and 6 equals "Strong Republican". We report again the coefficients on personal characteristics, as there are some intriguing differences across groups (see also the next table). For example, comparing columns (2) and (5) the coefficient on becoming unemployed is larger in absolute value (i.e. more negative) for the Right Wing sub-sample than the Left Wing. For left-wingers falling unemployed leads to a 8.4 percentage point drop in the probability of reporting themselves "Very Happy" compared to a 14 percentage point drop for right-wingers. Perhaps right-wingers are less prone to assume that their unemployed status is due to a public policy issue rather than to personal shortcomings. Being self-employed is only correlated with higher happiness for the Right Wing sub-sample, a finding that has some relevance for the empirical literature on entrepreneurship (e.g. Blanchflower and Oswald (1998)). Other differences include the finding that the coefficient on being male and on being black are more negative in the Right Wing sub-sample. Perhaps black conservatives, in addition to being black also feel some isolation from their racially defined community, which is overwhelmingly on the left of the political spectrum. The coefficients on being married and being in school are larger for the conservatives. The evidence also suggests that relative income or "status" is more important for right-wingers, where the coefficient on Top 2 Income Quartiles in regression (6) is 64 percent larger than that in column (3). A jump up into the top half of incomes increases the probability of reporting oneself as "Very Happy" by 3.4 percentage points for a right-winger compared to 1.8 percentage points for a left-winger. Again this result seems consistent with intuition. 
In terms of our macro variables, once the state unemployment rate is included, both groups are negatively affected by inequality but the effects are not significant. The coefficient on inequality for Right Wing respondents, however, is bigger in size (more negative) than that for the sub-sample of those leaning left. The opposite is true with the effect of state unemployment, as this turns negative and significant at the 4 percent level for the Left, a result consistent with the "partisan" model of macroeconomics. ${ }^{10}$ For the results reported in column 3 of Table 2-US, a one standard deviation increase in the unemployment rate (equal to 0.023) decreases the proportion of people reporting themselves as "Very Happy" by 1.3 percentage points and increases the proportion of people reporting themselves as "Not too Happy" by 0.7 percentage points.

In Table 3-US we break down the respondents between rich and poor. A respondent is classified as "rich" if he/she belongs to the top two income quartiles, and as "poor" otherwise. There are again interesting differences between the coefficients on personal characteristics across the two subsamples. Being self-employed has a positive and significant effect on individual happiness only in the rich sub-sample. The coefficient on Home, which is a dummy variable equal to one if the respondent is keeping the home, is negative and significant for the poor and positive and significant for the rich. Perhaps a poor housewife is stressed by the demand of keeping home, while a rich one can enjoy free time and the help of cleaning services, etc. So for one group staying home means hard work, for the other leisure time. While the poor display a negative statistically significant coefficient on having children, the same coefficient for the rich is smaller and often insignificant. This suggests that a high income may eliminate some of the stress associated with raising children, by allowing for more help, such as day care, nannies etc. The coefficient on being Black is always negative, but it is approximately double in absolute value in the sub sample for the Rich. This is a result that resembles the previous one on black conservatives. Finally, consistent with diminishing marginal utility, the effect of individual income in the poor sub-sample is significantly larger than the effect of income in the sub-sample of the rich. Comparing columns (2) and (4), a one standard deviation increase in income increases the probability of poor individuals reporting themselves as "Very Happy" by 11.9 percentage points compared to 4.2 percentage points for the rich.

\footnotetext{
${ }^{10}$ See Alesina, Roubini and Cohen (1997) on the partisan model of macroeconomic policy.
} 
Concerning inequality, we find a striking result, especially if compared with the results for Europe discussed below. The poor are unaffected by inequality, particularly after the state unemployment rate is included. On the contrary, it is the rich who show a significant and negative effect of increased unhappiness with inequality, even after controlling for the unemployment rate. For this group, a one standard deviation increase in inequality is equal to 58 percent of the effect of leaving self-employment. ${ }^{11}$ The poor, on the other hand, are affected by a higher unemployment rate (in addition to the personal costs of falling unemployed as picked up by the personal characteristic controls). For the rich, the unemployment rate does not seem to significantly affect their happiness, a result, again, which brings support to the partisan model of macroeconomic policy. Using the results for the poor reported in column 2 in Table 3-US, a one standard deviation increase in the unemployment rate decreases the proportion of poor people reporting themselves as "Very Happy" by 1.7 percentage points. In summary, the preceding results seem to suggest that there is an overall negative, marginally significant effect of inequality in the US. The effect comes in stronger when the sample is reduced to consider only individuals that are in the top half of the income distribution. There is no effect of inequality on the happiness of the poor or the left-wingers.

\section{Happiness and inequality in Europe}

Table 1-Eur presents pooled ordered logit regressions for the 12 European countries listed above for all countries and years for which happiness data exist. We have inequality data for only a part of this sample, giving us a total of 103,772 observations. All the regressions include country and year dummies.

As for the US results, we first present, in column 1, the results obtained using only individual controls. Comparing column 1 of Table 1-Eur with column 1 of Table 1-US one is struck by the similarities, not only of the sign and significance of the coefficients but often even by their size. This is important for two reasons. First, as for the case of Americans, the answers of Europeans about "happiness" seem to make sense. Second, the fact that basic individual characteristics like age, marital status and unemployment are correlated to the answer in similar ways in Europe and in the

\footnotetext{
${ }^{11}$ Using the coefficients in column (4) of Table 3-US, this number equals $0.032 * 2.768 / 0.153$.
} 
US suggest that the survey question is interpreted in a similar way in both places. Our results on individual effects are very similar to Di Tella et al. (1997).

In column 2 we add the inequality variable. Although it has a negative sign, the effect is only significant at the 14 percent level. The coefficient turns larger (more negative) and significant at the 2 percent level when unemployment and inflation rates are included in column 3 of Table 1-Eur. The coefficients on inflation and unemployment are both negative, but only the one on inflation is significant. This is in contrast with studies of Europe that do not restrict the sample according to data availability for inequality. The main results do not change, when controls for relative income or status effects are included in column 4.

Using the results in column 3 of Table 1-Eur, a one standard deviation increase in the Gini across Europe (equal to 0.043) decreases the proportion of people reporting themselves as "Very Satisfied" by 2.5 percentage points. A 10 percentage point increase in the Gini decreases the proportion of people reporting themselves as "Very Satisfied" by 5.5 percentage points and increases the proportion reporting themselves as "Not very/at all Satisfied" by 5.3 percentage points. Since 26.5 per cent of Europeans reported themselves as "Very Satisfied", a 10 percentage point increase in the Gini would correspond to a $20.7 \%$ drop to 21.0 per cent of people reporting themselves in the top happiness category. Since 19.6 per cent of Europeans reported themselves as "Not very/at all satisfied" it would also correspond to a $27 \%$ rise to 24.9 per cent of people reporting themselves in the bottom happiness category. To get a feel for the main changes in the data, note that between 1979 and 1982, as well as between 1987 and 1991, inequality fell in Italy whereas happiness rose. In the Netherlands between 1981 and 1985 inequality went up and happiness dropped. The same is true in the United Kingdom between 1980 and 1988. There was also a rise in inequality in Denmark between 1981 and 1987, a period where there also was a decline in happiness.

As for the macroeconomic variables, inflation, which varies both across time and across countries in Europe, seems important. A one standard deviation increase in the inflation rate (equal to 0.058) leads to a fall in the proportion of poor people reporting themselves as "Very Satisfied" of 3.0 percentage points. A 10 percentage point increase in the inflation rate corresponds to a drop to 21.5 per cent of people reporting themselves in the top happiness category (i.e. 5.0 percentage points less people reporting themselves as "very satisfied"). The effect of unemployment is negative but 
insignificant. These results hide different effects across income and ideological groups that we investigate below.

In Table 2-Eur we break down respondents into left and right. This is done using a question in the Eurobarometer asking respondents 'In political matters, people talk of 'the left' and 'the right'. How would you place your own views on this scale?" (from 1 to 10). Respondents were classified as being "left" if their response was in categories 1, 2, 3 or 4 and "right" if their response was 7, 8, 9, or 10. Note that both for the case of the US and of Europe, we leave out those who define themselves as centrist. The scale of the response of the left/right dimension was different in the US survey (as discussed above) and for the Europe survey. Our results are robust to reasonable changes in the right/left classification, for instance taking away categories 4 from the left and 7 from the right.

Again, the coefficients on individual characteristics provide interesting information. For example, and in direct contrast to what happens in the US, being self-employed increases happiness for the left sub-sample, but has no effect on the right. Column 1 in Table 2-Eur shows that the left exhibit a strong aversion to inequality, while the coefficient on this variable for the right-wing respondents is small and insignificant. Using the results in the most general specification in column 3 for the left, a one standard deviation increase in the Gini across Europe (equal to 0.043) decreases the proportion of leftists reporting themselves as "Very Satisfied" by 3.8 percentage points. Since 22.0 per cent of leftist Europeans reported themselves as "Very Satisfied", a one standard deviation increase in the Gini corresponds to a drop to 18.2 per cent of left leaning people reporting themselves in the top happiness category. These effects are quite large.

Inflation enters negatively in all regressions, but the size is 1.8 times larger (i.e. more negative) in the equation for the right, where it is also significant at the 3 percent level. Unemployment is insignificant for both left and right wing groups, in contrast to the findings of studies that use the full sample (i.e. Di Tella and MacCulloch (1998)).

Table 3-Eur presents the breakdown between rich and poor. A respondent is classified as rich if he/she is in the top two income quartiles and poor otherwise. While the poor are strongly affected by inequality, the rich Europeans seem to be indifferent to it. The size of the coefficient on inequality in column 3 is less than half than the corresponding coefficient in regression 1 of Table 3 Eur. Using the results in the most general specification in column 2 for the poor, a one standard 
deviation increase in the Gini across Europe decreases the proportion of poor people reporting themselves as "Very Satisfied" by 3.7 percentage points. It also increases the proportion of poor people reporting themselves as "Not very/at all Satisfied" by 2.2 percentage points. A one standard deviation increase in the Gini corresponds to a drop to 19.4 per cent of the poor reporting themselves in the top happiness category. Since 24.9 per cent of poor Europeans reported themselves as "Not very/at all satisfied" it also corresponds to a rise to 27.1 per cent of the poor reporting themselves in the bottom happiness category. Once again, these effects are large.

A different way of looking at size is to compare the effect of inequality on happiness with the size of the effect of other determinants. For instance, based upon the results of column (2) of Table 2-Eur, one can compute that for a European leftist an increase in inequality of one standard deviation of the Gini corresponds to a decrease in income equal to 89 percent of one standard deviation. ${ }^{12}$ It is also equal to 2.4 times the effect of leaving self-employment. ${ }^{13}$ For the European poor, a one standard deviation increase in Gini has the same effect as an increase in inflation of 7 percentage points. ${ }^{14}$ Alternatively a one standard deviation increase in inequality for the poor is equal in size to 33 percent of the effect of getting a divorce. ${ }^{15}$

\section{Comparing Europe and the United States}

The differences between the two sides of the Atlantic are striking. In Europe the poor and the left leaning respondents show a strong aversion to inequality. In the US, in contrast, the rich is the only group displaying aversion to inequality. Note that when we use other data sets on income distribution at the state level in the US, such as the census measures or the measures of inequality produced by the Economic Policy Institute from gross income data of the CPS, or the data presented in Blank (2001), the effect of inequality on individual happiness for the US is never statistically significant for the full sample or in the sub-sample of the poor. We focus on the WuPerloff-Golan (2002) inequality data since it seems to be particularly accurate for the purposes of our paper, but, again, remember that this the data set that gives he strongest effect of inequality on happiness in the US and it is limited to an effect on the rich.

\footnotetext{
12 This number is calculated from the coefficients in column (2) of Table2-Eur and equals $0.043 * 6.344 /(6.7 \mathrm{e}-5 * 4570)$.

${ }^{13}$ Using the coefficients in column (2) of Table2-Eur, this number equals $0.043 * 6.344 / 0.112$.

${ }^{14}$ Using the coefficients in column (2) of Table3-Eur, this number equals $0.043 * 4.137 / 2.675$.
} 
We summarize the differences on the effect of inequality in Europe and the US, in Table 4. The entries of this table represent the predicted change in the proportion of people in the top happiness category due to a one standard deviation change in inequality. They are obtained from column 3 of Table 1, columns 2 and 5 of Table 2 and columns 2 and 4 of Table 3 . The last line of Table 4, labeled "Different to US?" shows the statistical significance of the test that the regression coefficients on inequality (from which the numbers in each column are derived) are different in Europe.

Column 1 shows that the effect of inequality in the entire sample is larger in absolute value and more statistically significant for Europe than for the US. Even though the test on the statistical difference between the two coefficients is only valid at the 28 per cent, the magnitude of the European effect is almost twice as large and more precisely estimated. The following 4 columns show that while in Europe it is the leftists and the poor who dislike in equality, in the US it is only the rich.

Probably the most striking result of all is the complete lack of any effect of inequality on the happiness of the American poor and the American left. The difference with the European poor and European left is strong and statistically significant. The coefficients on the rich in the US and Europe have approximately the same value, but it is insignificantly different from zero in Europe and highly significant in the US. In summary, it is the European poor who drive the strong negative effects of inequality on happiness in the European sample, and it is the rich who drive the weaker effect of inequality on happiness in the US sample.

There are two potential explanations for our finding that Europeans dislike inequality, while the effect on Americans is weaker. The first one involves taste: in Europe there may be higher preferences for equality. That is, equality enters the utility function of Europeans with higher weights than in the utility function of Americans. In fact, Thurow (1971) argues that equality is a luxury good, an observation consistent with the fact that the share of government transfers over GDP is higher in richer countries. The rich in the US then should like equality, precisely because of

\footnotetext{
${ }^{15}$ Using the coefficients in column (2) of Table3-Eur, this number is $0.043 * 4.137 / 0.537$.
} 
this luxury good argument. However this interpretation is not consistent with our results for Europe, where the rich do not seem to be bothered by inequality while the poor are. ${ }^{16}$

A more plausible interpretation is in terms of differences in perceived social mobility, rather than relying solely on "taste for equality". If Americans perceive their country as a more mobile society than Europe, where people have opportunities to move up (or down), present day inequality levels may have little influence on individual utility. In other words, relative to their European counterparts, the American rich feel that they have higher chance of moving down in the income ladder; conversely the European poor feel that their chances of moving up the income ladder are lower than in the US. This explains why the American rich may be more worried about inequality than European rich and the other way around for the poor. This hypothesis is supported by the vast analysis of poll data by Ladd and Bowman (1998). They find that Americans are willing to tolerate quite large disparities in wealth as long as they perceive that wealth is the result of effort and that everybody can make it if enough effort and talent is devoted to the task. Obviously not everybody believes that opportunities are truly equal for everybody, but polls show that the more people perceive that the majority of people have reasonable opportunities, the more tolerance there is for inequality.

Note that what matters for this potential explanation to hold is that perceived rather than actual mobility is different. According to the World Value Survey, 71 per cent of Americans believe that the poor have a chance of escaping from poverty. In Europe that number is 40 per cent. ${ }^{17}$ Whether or not this perception of higher social mobility in the US is correct or not is irrelevant for our purposes here since we are dealing with people's views, so their perception is what matters. The debate on comparing actual mobility across countries is very important and intriguing, but we do not have anything to add on this point in the present paper. Suffice it to say that data problems make conclusive tests of this hypothesis concerning social mobility on the two sides of the Atlantic almost impossible, as noted by Atkinson, Bourgignon and Morrison (1992).

\footnotetext{
${ }^{16}$ In fact, following the logic of this argument, it is enough that equality is a normal good to make our result for Europe not compatible with a "taste" interpretation.

17 The same numbers are reported in Alesina, Glaeser and Sacerdote (2001).
} 


\section{Conclusion}

Countries differ greatly in the degree of income inequality that they tolerate, even at similar stages of development. European observers object to the higher (and, for much of the past few decades, growing) inequality in the US. American commentators argue that European society's "obsession" with inequality stifles creativity and creates a vicious circle of welfare addiction of the poor. Do these differences of opinion simply reflect different preferences about the merits of equality in the two sides of the Atlantic? Furthermore, is a preference for equality just a matter of "taste," or does it reflect something else in society, such as the level of social mobility?

We use the answers to a simple well-being question. We simply correlate the answers to the wellbeing question asked to thousands of individuals in Europe and America over many years with measured levels of inequality. All that this method requires is an individual's ability to introspect and evaluate his or her own happiness.

Our results show that, controlling for personal characteristics of the respondents, state/country effects and year effects, Americans seem to be less affected by inequality than Europeans. We then investigate differences across income and ideological groups. We find that the rich and the rightwingers in Europe are unaffected by inequality. Instead, we identify strong negative effects of inequality on the happiness of the European poor and leftists. In the US, the poor and the leftwingers are not affected by inequality, whereas the effect on the rich is negative and well defined.

This suggests that European aversion to inequality does not originate in different preferences in the US and Europe. Suppose that "equality" is a luxury good, the demand for which rises with income more than proportionally, or even a normal good. Then we should find that European rich dislike inequality more than the European poor, like in the US. A more reasonable interpretation is that opportunities for mobility are (or are perceived to be) higher in the US than in Europe. 


\section{References}

1. Alesina, A., and E. La Ferrara (2000), "Preferences for Redistribution in the Land of Opportunity," unpublished.

2. Alesina A. E Glaeser and B. Sacerdote (2001) 'Why doesn't the United States have a Europeanstyle Welfare State?” Brookings papers on Economic Activity, fall, 187-277.

3. Alesina, A., N. Roubini and G. Cohen (1997), Political Cycles and the Macroeconomy, MIT Press.

4. Atkinson, A., F. Bourguignon and C. Morrison (1992), Empirical Studies of Income Mobility. London: Harwood Academic Publishers.

5. Atkinson, A. and A. Brandolini (1999), "Promise and Pitfalls in the Use of 'Secondary' DataSets: Income Inequality in OECD countries”, Nuffield College Working Paper, Oxford.

6. Benabou, R. and E. Ok (2000), "Social Mobility and the Demand for Redistribution," The Quarterley Journal of Economics, forthcoming.

7. Bjorklund, A. and M. Janiti (1997), "Intergenerational Income Mobility in Sweden Compared to the United States," American Economic Review, December, 1009-18.

8. Blanchflower, D. and A. Oswald (2000) "Well-Being Over Time in Britain and the USA", mimeo.

9. Blanchflower, D. and A. Oswald (1998) "What Makes an Entrepreneur?", Journal of Labor Economics, 16, 26-60.

10. Blank, Rebecca (2001) "What Causes Public Assistance Caseloads to Grow?", Journal of Human Resources, 36(1): 85-118.

11. Boeri, Tito, Axel Borsch-Supan and Guido Tabellini (2000) "Would you like to Shrink the Welfare State? A Survey of European Citizens." Economic Policy 32:(7-50).

12. Bradburn, N. (1969) The Structure of Psychological Well-Being, Chicago: Aldine Publishing.

13. Clark, A. and A. Oswald (1994) "Unhappiness and Unemployment", Economic Journal, 104, 64859.

14. Corneo, G. (2000), "Inequality and the State: Comparing US and German Preferences," unpublished.

15. Corneo, G. and H. P. Gruner (2000), "Individual Preferences for Political Redistribution," unpublished.

16. Davis, J. A. and T. W. Smith (1994), General Social Surveys, 1972-1994, Machine-readable data file, Chicago: National Opinion Research Center (producer), Storrs, CT: The Roper Center for 
Public Opinion Research (distributor).

17. Deininger, K. and L. Squire (1996) “A New Data Set Measuring Income Inequality”, World Bank Economic Review, September, 10(3), 565-91.

18. Diener, Ed, Suh, Eunkook, Lucas, Richard and Heidi Smith (1999) "Subjective Well-Being: Three Decades of Progress, Psychological Bulletin, 125 (2), 276-303.

19. Diener, E. (1984) “Subjective Well-Being”, Psychological Bulletin, 93, 542-575.

20. Di Tella, R. and R. MacCulloch (1996) "An Empirical Study of Unemployment Benefit Preferences", Discussion paper 179, IES, Oxford University.

21. Di Tella, R., R. MacCulloch and A. Oswald (1997) "The Macroeconomics of Happiness", CEP working paper 19.

22. Di Tella, R. and R. MacCulloch (1998) "Partisan Social Happiness", mimeo.

23. Di Tella, R., R. MacCulloch and A. Oswald (1999) "Preferences over Inflation and Unemployment: Evidence form Surveys of Happiness", forthcoming The American Economic Review.

24. Easterlin, R. (1974) "Does Economic Growth Improve the Human Lot? Some Empirical Evidence", in Nations and Households in Economic Growth: Essays in Honour of Moses Abramovitz, edited by P. David and M. Reder, Academic Press: New York and London.

25. Ekman, P., Davidson, R. and W. Friesen (1990) "The Duchenne Smile: Emotional Expression and Brain Physiology II", Journal of Personality and Social Psychology, 58, 342-53.

26. Frey, B. and A. Stutzer (1999) "Happiness, Economy and Institutions", mimeo.

27. Fordyce, M. (1988) "A Review of Research on Happiness Measures: A Sixty Second Index of Happiness and Mental Health", Social Indicators Research, 20: 355-81.

28. Granato, J., Inglehart, R. and D. Leblang (1996) "Cultural Values, Stable Democracy and Economic Development: Reply”, American Journal of Political Science, 40(3), 680-96.

29. Inglehart, R. (1990) Culture Shift, Chicago University Press: Chicago.

30. Inglehart, R. (1996) "The Diminishing Utility of Economic Growth: From Maximizing Security toward Maximizing Subjective Well-Being", Critical Review, Vol. 10 (4). p 509-31.

31. Inglehart, R. Reif, K. and A. Melich (1994) European Communities Studies, 1970-92: Cumulative File, $3^{\text {rd }}$ ICPSR version, Ann Arbor, MI.

32. Kahneman, Daniel and Richard Thaler (1991) "Economic Analysis and the Psychology of Utility: Applications to Compensation Policy", American Economic Review, 81(2), 341-6. 
33. Kahneman, D., Wakker, P.P. and R. Sarin (1997) "Back to Bentham? Explorations of Experienced Utility”, Quarterly Journal of Economics, 112, 357-406.

34. Kahneman, Daniel, Diener, Ed and Norbert Schwartz (eds) (1999) Well-Being: The Foundations of Hedonic Psychology. New York: Russell Sage Foundation.

35. Konow, J. and J. Earley (1999) "The Hedonistic Paradox: Is Homo-Economicus Happier?" mimeo.

36. Ladd, Everett Carl and Karlyn Bowman (1998) Attitudes Toward Economic Inequality, Washington, DC, AEI Press.

37. Meltzer, A. and S. Richards (1981), “A Rational Theory of the Size of Government," Journal of Political Economy, 89, 914-27.

38. Moulton, B. (1986) "Random Groups Effects and the Precision of Regression Estimates", Journal of Econometrics, 32, 385-97.

39. Morawetz, D. et al (1977). "Income Distribution and Self-Rated Happiness: Some Empirical Evidence”, Economic Journal, 87, 511-522.

40. Ng, Y-K. (1996) "Happiness Surveys: Some Comparability Issues and an Exploratory Survey Based on Just Perceivable Increments", Social Indicators Research, 38, 127.

41. Pavot, W. (1991) "Further Validation of the Satisfaction with Life Scale: Evidence for the Convergence of Well-Being Measures", Journal of Personality Assessment, 57, 149-161.

42. Piketty, T. (1995), "Social Mobility and Redistributive Politics," The Quarterly Journal of Economics, $110,551-84$.

43. Ravallion, M. and M. Lokshin (2000), "Who Wants to Redistribute? The Tunnel Effect in 1990 Russia," Journal of Public Economics, 76, 87-104.

44. Rorer, L. (1965) “The Great Response-style myth”, Psychological Bulletin, 63: 129-56.

45. Sandvik, E., Diener, E. and L. Seidlitz (1993) "Subjective Well-Being: The Convergence and Stability of Self and Non Self Report Measures", Journal of Personality, 61-3: 317-42.

46. Shedler, J., Mayman, M. and M. Manis (1993) "The Illusion of Mental Health", American Psychologist, 48(11): 1117-

47. Siedlitz, L., Wyer, R. and E. Diener (1997) "Cognitive Correlates of Subjective Well-Being: The Processing of Valenced events by Happy and Unhappy Persons", Journal of Research in Personality, 31(1): 240-56.

48. Sutton, S. and R. Davidson (1997) "Prefrontal Brain Symmetry: A Biological Substrate of the Behavioral Approach and Inhibition Systems", Psychological Science, 8(3), 204-10. 
49. Stutzer, A. and R. Lalive (2000) "The Role of Social Norms in Job Searching and Subjective Well-Being", mimeo.

50. Tanzi, V. and L. Schuknecht (2000) Public Spending in the $20^{\text {th }}$ Century, Cambridge University Press, Cambridge UK.

51. Thurow, L. (1971) “The Income Distribution as a Pure Public Good”, Quarterly Journal of Economics, 83, 327.

52. Tinbergen, J. (1991) “On the Measurement of Welfare”, Journal of Econometrics, 50(7), 7-13.

53. van Praag, B. (1991) “Ordinal and Cardinal Utility", Journal of Econometrics, 50(7), 69-89.

54. Winkelmann, Liliana and Rainer Winkelmann (1998) "Why are the Unemployed so Unhappy? Evidence from Panel Data", Economica, 65 (257), 1-15.

55. Wu, Ximing, Jeffrey Perloff and Amos Golan (2002) "Effects of Government Policies on Income Distribution and Welfare", UC Berkeley working paper, iirwps-086-02. 
Table A-US

Happiness in the United States: 1981 to 1996.

\begin{tabular}{|c|c|c|c|c|}
\hline \multirow{2}{*}{$\begin{array}{l}\text { Reported } \\
\text { Happiness }\end{array}$} & \multirow[t]{2}{*}{ All } & \multirow[t]{2}{*}{ "Unemployed } & \multicolumn{2}{|c|}{$\begin{array}{ll}\text { Marital Status } \\
\end{array}$} \\
\hline & & & Married & Divorced \\
\hline Very Happy & 31.29 & 18.85 & 39.06 & 19.39 \\
\hline Pretty Happy & 57.36 & 52.35 & 53.90 & 62.84 \\
\hline Not too Happy & 11.35 & 28.80 & 7.04 & 17.77 \\
\hline
\end{tabular}

\begin{tabular}{lcc|cccc}
\hline \hline $\begin{array}{l}\text { Reported } \\
\text { Life Satisfaction }\end{array}$ & Partisan & Support & \multicolumn{3}{c}{ Income } & Quartiles \\
\cline { 2 - 6 } & Left & Right & $\begin{array}{c}1^{\text {st }} \\
\text { (Lowest) }\end{array}$ & 2nd & 3rd & $\begin{array}{c}\text { 4th } \\
\text { (Highest) }\end{array}$ \\
\hline Very Happy & 28.53 & 36.02 & 22.20 & 28.73 & 33.11 & 40.48 \\
Pretty Happy & 58.60 & 55.69 & 57.91 & 59.30 & 58.74 & 53.72 \\
Not too Happy & 12.87 & 8.29 & 19.89 & 11.97 & 8.15 & 5.80 \\
\hline \hline
\end{tabular}

Note: Based on 19,895 observations. All numbers are expressed as a percentage.

Table B-US

Summary Statistics for the United States: 1981 to 1996.

\begin{tabular}{lccccc}
\hline \hline Variable & Obs. & Mean & Std. Dev. & Min. & Max. \\
\hline PERSONAL INCOME & 19,895 & 35,316 & 24,982 & 491 & 98,468 \\
INCOME INEQUALITY & 616 & 0.337 & 0.032 & 0.271 & 0.446 \\
UNEMPLOYMENT RATE & 616 & 0.065 & 0.023 & 0.024 & 0.180 \\
INFLATION RATE & 616 & 0.037 & 0.011 & 0.018 & 0.060 \\
MURDERS & 616 & 6.846 & 3.594 & 0.200 & 20.300 \\
AUTO THEFT & 616 & 420.248 & 224.409 & 96 & 1067 \\
& & & & & \\
\hline \hline
\end{tabular}


Table A-Eur

Life Satisfaction in Europe: 1975 to 1992.

\begin{tabular}{|c|c|c|c|c|}
\hline \multirow{2}{*}{$\begin{array}{l}\text { Reported } \\
\text { Life Satisfaction }\end{array}$} & \multirow[t]{2}{*}{ "All } & \multirow[t]{2}{*}{ Unemployed } & \multicolumn{2}{|c|}{ Marital Status } \\
\hline & & & Married & Divorced \\
\hline Very satisfied & 26.46 & 15.21 & 28.79 & 18.61 \\
\hline Fairly satisfied & 53.96 & 44.21 & 54.04 & 51.00 \\
\hline $\begin{array}{l}\text { Not very / Not at all } \\
\text { satisfied }\end{array}$ & 19.59 & 40.59 & 17.17 & 30.39 \\
\hline
\end{tabular}

\begin{tabular}{lcc|cccc}
\hline \hline $\begin{array}{l}\text { Reported } \\
\text { Life Satisfaction }\end{array}$ & Partisan & Support & \multicolumn{3}{c}{ Income } & Quartiles \\
\cline { 2 - 6 } & Left & Right & $\begin{array}{c}1 \text { st } \\
\text { (Lowest) }\end{array}$ & $2^{\text {nd }}$ & 3rd & $\begin{array}{c}\text { 4th } \\
\text { (Highest) }\end{array}$ \\
\hline Very satisfied & 21.98 & 34.88 & 21.90 & 24.36 & 26.81 & 32.58 \\
Fairly satisfied & 54.15 & 50.97 & 49.52 & 54.54 & 56.71 & 54.96 \\
$\begin{array}{l}\text { Not very / Not at } \\
\text { all satisfied }\end{array}$ & 23.87 & 14.16 & 28.58 & 21.10 & 16.48 & 12.47 \\
\hline \hline
\end{tabular}

Note: Based on 103,773 observations. All numbers are expressed as a percentage.

Table B-Eur

Summary Statistics for Europe: 1975 to 1992.

\begin{tabular}{lccccc}
\hline \hline Variable & Obs. & Mean & Std. Dev. & Min. & Max. \\
\hline PERSONAL INCOME & 103,773 & 11,198 & 4,570 & 3,582 & 24,528 \\
INCOME INEQUALITY & 67 & 0.304 & 0.043 & 0.229 & 0.430 \\
UNEMPLOYMENT RATE & 67 & 0.093 & 0.041 & 0.016 & 0.220 \\
INFLATION RATE & 67 & 0.081 & 0.058 & -0.007 & 0.245 \\
\hline \hline
\end{tabular}


Table 1-US: The Determinants of Happiness in the US, 1981-96.

\begin{tabular}{|c|c|c|c|c|}
\hline Dep Var: Happiness & (1) & $(2)$ & $(3)$ & $(4)$ \\
\hline Inequality & & $\begin{array}{l}-2.949 * \\
(1202)\end{array}$ & $\begin{array}{l}-2.136 \\
(1.162)\end{array}$ & $\begin{array}{l}-2.102 \\
1157)\end{array}$ \\
\hline & & -0.019 & -0.014 & -0.014 \\
\hline \multirow[t]{3}{*}{ Unemployment Rate } & & & -2.321 & -2.328 \\
\hline & & & (1.363) & $(1.360)$ \\
\hline & & & -0.011 & -0.011 \\
\hline \multicolumn{5}{|l|}{ Personal Characteristics } \\
\hline \multirow[t]{2}{*}{ Unemployed } & $-0.637 *$ & $-0.633 *$ & $-0.630 *$ & $-0.623 *$ \\
\hline & $(0.106)$ & $(0.104)$ & $(0.104)$ & $(0.105)$ \\
\hline \multirow[t]{2}{*}{ Self employed } & 0.049 & 0.051 & 0.050 & 0.055 \\
\hline & $(0.040)$ & $(0.040)$ & $(0.039)$ & $(0.039)$ \\
\hline \multirow[t]{2}{*}{ Retired } & 0.011 & 0.013 & 0.014 & 0.020 \\
\hline & $(0.055)$ & $(0.055)$ & $(0.055)$ & $(0.056)$ \\
\hline \multirow[t]{2}{*}{ School } & 0.218 & 0.218 & 0.218 & 0.224 \\
\hline & $(0.134)$ & $(0.134)$ & $(0.134)$ & $(0.135)$ \\
\hline \multirow[t]{2}{*}{ Home } & -0.038 & -0.037 & -0.036 & -0.030 \\
\hline & $(0.048)$ & $(0.048)$ & $(0.048)$ & $(0.048)$ \\
\hline \multirow[t]{2}{*}{ Other } & $-0.563 *$ & $-0.560 *$ & -0.558 & $-0.547 *$ \\
\hline & $(0.107)$ & $(0.108)$ & 0.107 & $(0.107)$ \\
\hline \multirow[t]{2}{*}{ Male } & $-0.162 *$ & $-0.163 *$ & $-0.162 *$ & $-0.164 *$ \\
\hline & $(0.029)$ & $(0.029)$ & $(0.029)$ & $(0.030)$ \\
\hline \multirow[t]{2}{*}{ Age } & $-0.037 *$ & $-0.037^{*}$ & $-0.037 *$ & $-0.038 *$ \\
\hline & $(0.007)$ & $(0.007)$ & $(0.007)$ & $(0.007)$ \\
\hline \multirow[t]{2}{*}{ Age Squared } & $4.7 \mathrm{e}-4^{*}$ & $4.6 \mathrm{e}-4 *$ & $4.7 e-4 *$ & $4.4 \mathrm{e}-4^{*}$ \\
\hline & $(7.5 e-5)$ & $(7.5 e-5)$ & $(7.4 e-5)$ & $(6.3 e-5)$ \\
\hline \multirow[t]{2}{*}{ Education: College } & $0.144^{*}$ & $0.145^{*}$ & $0.145^{*}$ & $0.143^{*}$ \\
\hline & $(0.031)$ & $(0.031)$ & $(0.031)$ & $(0.031)$ \\
\hline \multirow[t]{2}{*}{ Graduate } & $0.171^{*}$ & $0.173^{*}$ & $0.173^{*}$ & $0.173^{*}$ \\
\hline & $(0.055)$ & $(0.055)$ & $(0.055)$ & $(0.055)$ \\
\hline \multirow[t]{2}{*}{ Marital Status: Married } & $0.631^{*}$ & $0.630 *$ & $0.630 *$ & $0.620 *$ \\
\hline & $(0.047)$ & $(0.047)$ & $(0.047)$ & (0.049) \\
\hline \multirow[t]{2}{*}{ Divorced } & $-0.174 *$ & $-0.174 *$ & $-0.175^{*}$ & $-0.175^{*}$ \\
\hline & $(0.073)$ & $(0.073)$ & $(0.073)$ & $(0.073)$ \\
\hline \multirow[t]{2}{*}{ Separated } & $-0.487 *$ & $-0.485^{*}$ & $-0.486 *$ & $-0.486^{*}$ \\
\hline & $(0.105)$ & $(0.105)$ & $(0.105)$ & $(0.105)$ \\
\hline \multirow[t]{2}{*}{ Widowed } & $-0.345 *$ & $-0.346 *$ & $-0.345^{*}$ & $-0.349 *$ \\
\hline & $(0.078)$ & $(0.077)$ & $(0.077)$ & $(0.078)$ \\
\hline \multirow[t]{5}{*}{ No. of children: } & $-0.184 *$ & -0.184 & $-0.183^{*}$ & $-0.182 *$ \\
\hline & $(0.035)$ & $(0.035)$ & $(0.035)$ & $(0.035)$ \\
\hline & $-0.140 *$ & $-0.141^{*}$ & $-0.140 *$ & $-0.139 *$ \\
\hline & $(0.044)$ & $(0.044)$ & $(0.044)$ & $(0.045)$ \\
\hline & $-0.164 *$ & $-0.164 *$ & $-0.162 *$ & $-0.161^{*}$ \\
\hline$>3$ & $(0.049)$ & $(0.049)$ & $(0.049)$ & $(0.049)$ \\
\hline \multirow[t]{2}{*}{ Income } & $9.9 \mathrm{e}-6^{*}$ & $1.0 \mathrm{e}-05$ & $1.0 \mathrm{e}-05$ & $8.3 e-6^{*}$ \\
\hline & $(8.7 e-7)$ & $(8.7 e-07)$ & $(8.7 e-07)$ & $(9.7 e-7)$ \\
\hline Top 2 Income Quartiles: & & & & $0.116 *$ \\
\hline & & & & $(0.056)$ \\
\hline Black & $-0.393 *$ & $-0.393 *$ & $-0.394 *$ & $-0.393 *$ \\
\hline & $(0.049)$ & $(0.048)$ & $(0.048)$ & $(0.048)$ \\
\hline Obs. & 19,895 & 19,895 & 19,895 & 19,895 \\
\hline
\end{tabular}

Note: [1] Ordered logit regressions, include State and year dummies. [2] Bold-face denotes significant at the 10 percent level; Starred bold-face at the 5 per cent level. [3] Cut points in Appendix 2. The cell below the standard error report the predicted change in the proportion of people in the top happiness category due to a one-standard deviation change in the corresponding explanatory variable (see text for more detail). 
Table 2-US: The Determinants of Happiness in the US, 1981-96, Left and Right.

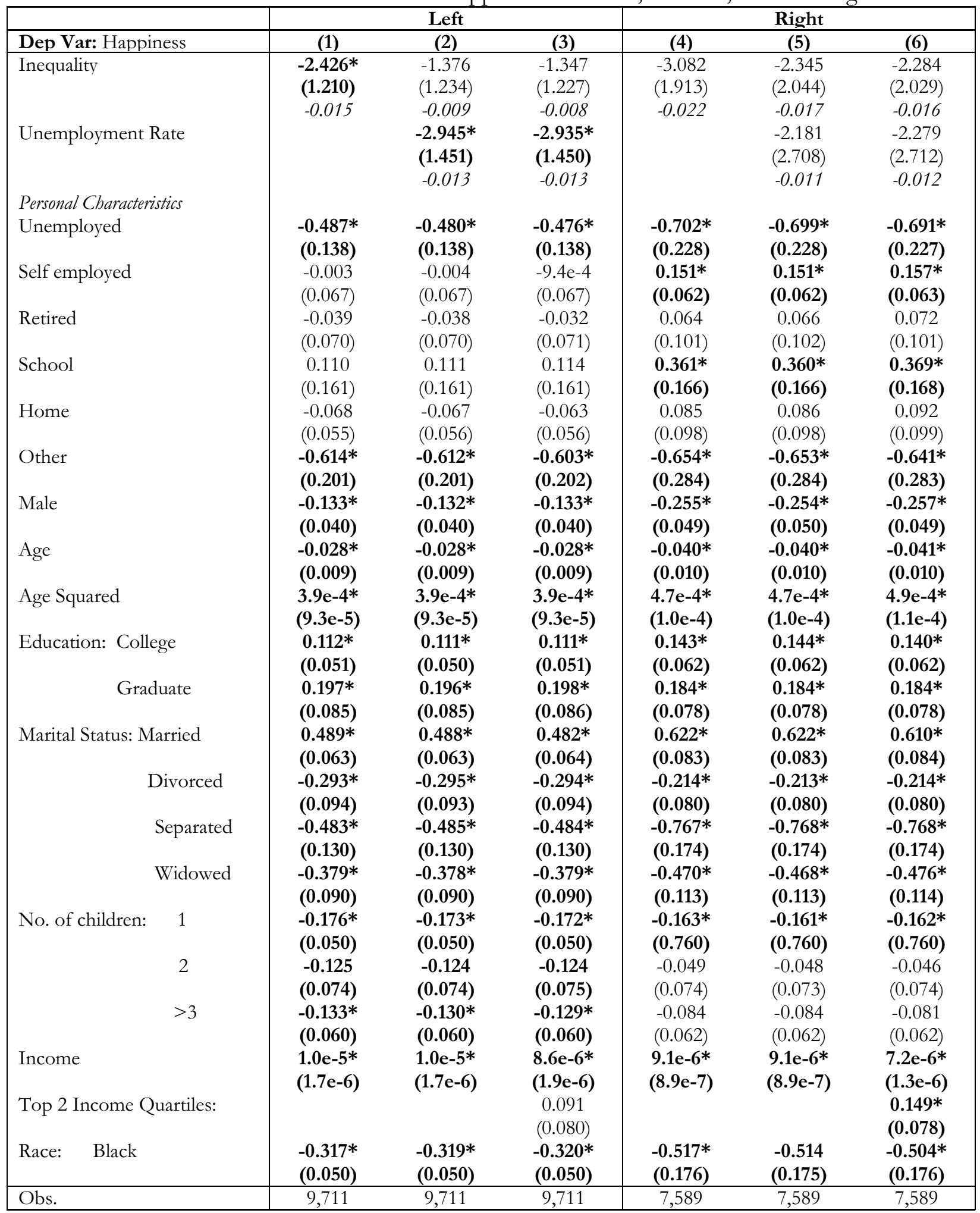

Note: [1] Ordered logit regressions, include State and year dummies. [2] Bold-face denotes significant at the 10 percent level; Starred bold-face at the 5 per cent level. [3] Cut points in Appendix 2. The cell below the standard error (in italics) reports the predicted change in the proportion of people in the top happiness category due to a onestandard deviation change in the corresponding explanatory variable (see text for more detail). 
Table 3-US: The Determinants of Happiness in the US, 1981-96, Poor and Rich.

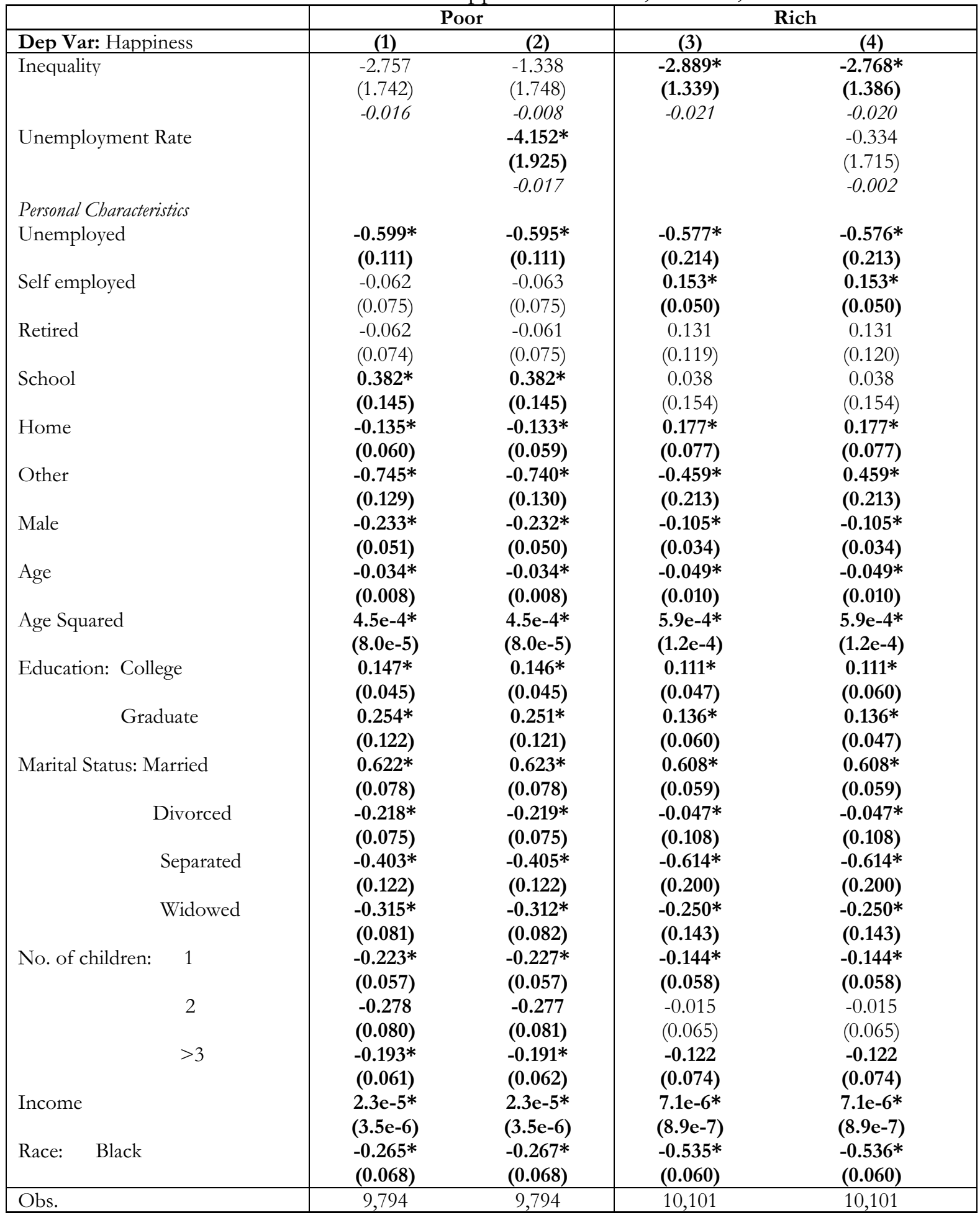

Note: [1] Ordered logit regressions, include State and year dummies. [2] Bold-face denotes significant at the 10 percent level; Starred bold-face at the 5 per cent level. [3] Cut points in Appendix 2. The cell below the standard error (in italics) reports the predicted change in the proportion of people in the top happiness category due to a one-standard deviation change in the corresponding explanatory variable (see text for more detail). 
Table 1-Eur: The Determinants of Happiness Across 12 European Nations, 1975-92.

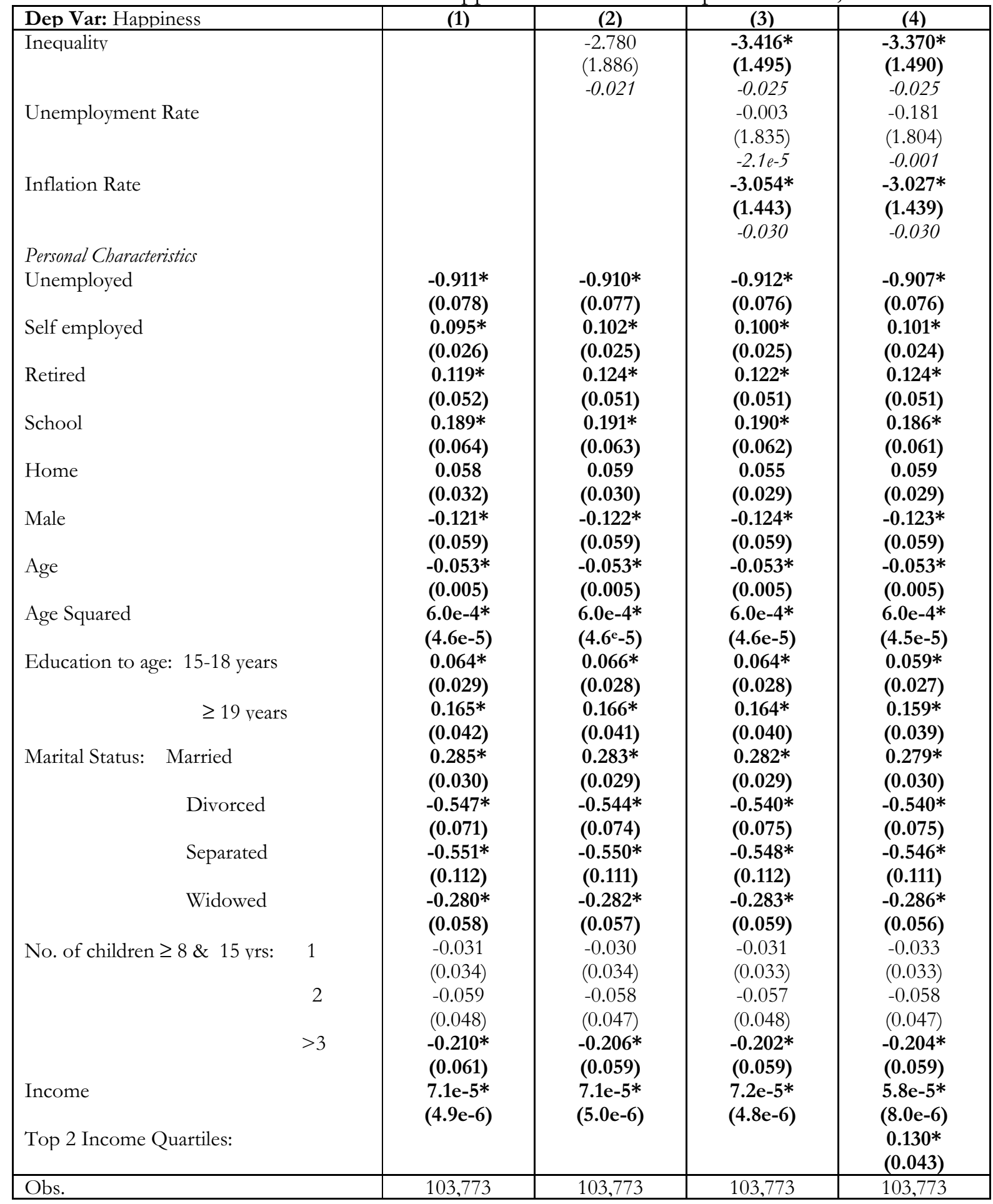

Note: [1] Ordered logit regressions, include country and year dummies. [2] Bold-face denotes significant at the 10 percent level; Starred bold-face at the 5 per cent level. [3] Cut points in Appendix 2. The cell below the standard error (in italics) reports the predicted change in the proportion of people in the top happiness category due to a one-standard deviation change in the corresponding explanatory variable (see text for more detail). 
Table 2-Eur: Happiness Across 12 European Nations,1975-92, Left and Right.

\begin{tabular}{|c|c|c|c|c|c|c|c|}
\hline \multirow{2}{*}{\multicolumn{2}{|c|}{ Dep Var: Happiness }} & \multicolumn{3}{|c|}{ Left } & \multicolumn{3}{|c|}{ Right } \\
\hline & & $(1)$ & $(2)$ & (3) & $(4)$ & $(5)$ & $(6)$ \\
\hline \multirow{3}{*}{\multicolumn{2}{|c|}{ Inequality }} & $-7.095 *$ & $-6.344 *$ & $-6.178 *$ & -1.590 & -1.408 & -1.218 \\
\hline & & (1.130) & (1.021) & (1.039) & (2.118) & $(1.736)$ & $(1.786)$ \\
\hline & & -0.044 & -0.039 & -0.038 & -0.015 & -0.013 & -0.011 \\
\hline \multirow{3}{*}{\multicolumn{2}{|c|}{ Unemployment Rate }} & & 2.268 & 1.846 & & 0.240 & -0.007 \\
\hline & & & $(2.051)$ & $(2.055)$ & & $(2.340)$ & $(2.299)$ \\
\hline & & & 0.015 & 0.012 & & 0.002 & $-6.3 e-5$ \\
\hline \multirow{3}{*}{\multicolumn{2}{|c|}{ Inflation Rate }} & & -1.739 & -1.858 & & $-3.250 *$ & $-3.295 *$ \\
\hline & & & (1.634) & $(1.672)$ & & (1.498) & $(1.503)$ \\
\hline & & & -0.015 & -0.016 & & -0.040 & -0.040 \\
\hline \multicolumn{8}{|l|}{ Personal Characteristics } \\
\hline \multirow{2}{*}{\multicolumn{2}{|c|}{ Unemployed }} & $-0.920 *$ & $-0.924 *$ & $-0.918 *$ & $-0.809 *$ & $-0.811 *$ & $-0.804 *$ \\
\hline & & $(0.069)$ & $(0.068)$ & $(0.069)$ & $(0.067)$ & $(0.067)$ & $(0.067)$ \\
\hline \multirow{2}{*}{\multicolumn{2}{|c|}{ Self employed }} & $0.113 *$ & $0.112 *$ & $0.112 *$ & 0.009 & 0.009 & 0.010 \\
\hline & & $(0.045)$ & $(0.046)$ & $(0.044)$ & $(0.039)$ & $(0.039)$ & $(0.040)$ \\
\hline \multirow{2}{*}{\multicolumn{2}{|c|}{ Retired }} & 0.056 & 0.054 & 0.058 & $0.219 *$ & $0.218^{*}$ & $0.220 *$ \\
\hline & & $(0.040)$ & $(0.041)$ & $(0.041)$ & $(0.086)$ & $(0.087)$ & $(0.087)$ \\
\hline \multirow{2}{*}{\multicolumn{2}{|c|}{ School }} & $0.061^{*}$ & $0.059 *$ & 0.054 & $0.277^{*}$ & $0.275^{*}$ & $0.267^{*}$ \\
\hline & & $(0.070)$ & $(0.070)$ & $(0.070)$ & $(0.076)$ & $(0.076)$ & $(0.075)$ \\
\hline \multirow{2}{*}{\multicolumn{2}{|c|}{ Home }} & -0.015 & -0.018 & -0.012 & $0.070 *$ & $0.068^{*}$ & $0.072 *$ \\
\hline & & $(0.054)$ & $(0.053)$ & $(0.055)$ & $(0.021)$ & $(0.021)$ & $(0.022)$ \\
\hline \multirow{2}{*}{\multicolumn{2}{|c|}{ Male }} & -0.096 & -0.098 & -0.096 & $-0.213^{*}$ & $-0.213^{*}$ & $-0.213 *$ \\
\hline & & $(0.079)$ & $(0.079)$ & $(0.080)$ & $(0.043)$ & $(0.043)$ & $(0.044)$ \\
\hline \multirow{2}{*}{\multicolumn{2}{|c|}{ Age }} & $-0.058 *$ & $-0.058 *$ & $-0.058 *$ & $-0.048^{*}$ & $-0.048 *$ & $-0.048 *$ \\
\hline & & $(0.006)$ & $(0.006)$ & $(0.006)$ & $(0.008)$ & $(0.008)$ & $(0.008)$ \\
\hline \multirow{2}{*}{\multicolumn{2}{|c|}{ Age Squared }} & $6.4 \mathrm{e}-4 *$ & $6.4 \mathrm{e}-4 *$ & $6.4 \mathrm{e}-4 *$ & $5.4 \mathrm{e}-4 *$ & $5.4 \mathrm{e}-4 *$ & $5.4 \mathrm{e}-4 *$ \\
\hline & & $\left(6.1^{e}-5\right)$ & $(6.1 e-5)$ & $(6.0 e-5)$ & $(7.7 e-5)$ & $(7.7 e-5)$ & $(7.6 e-5)$ \\
\hline \multirow{2}{*}{\multicolumn{2}{|c|}{ Education to age: $15-18$ years }} & 0.051 & 0.046 & -0.001 & $0.076 *$ & $0.036 *$ & $0.066^{*}$ \\
\hline & & $(0.034)$ & $(0.034)$ & $(0.035)$ & $(0.029)$ & $(0.029)$ & $(0.029)$ \\
\hline \multirow{2}{*}{\multicolumn{2}{|c|}{$\geq 19$ years }} & $0.124 *$ & $0.123 *$ & $0.118 *$ & $0.145^{*}$ & $0.141 *$ & $0.134 *$ \\
\hline & & $(0.047)$ & $(0.047)$ & $(0.047)$ & $(0.046)$ & $(0.045)$ & $(0.044)$ \\
\hline \multirow{2}{*}{\multicolumn{2}{|c|}{ Marital Status: Married }} & $0.376^{*}$ & $0.373 *$ & $0.367 *$ & $0.194 *$ & $0.193 *$ & $0.190 *$ \\
\hline & & $(0.035)$ & $(0.035)$ & $(0.035)$ & $(0.038)$ & $(0.039)$ & $(0.039)$ \\
\hline \multirow{2}{*}{\multicolumn{2}{|c|}{ Divorced }} & $-0.401 *$ & $-0.400 *$ & $-0.401 *$ & $-0.632 *$ & $-0.624 *$ & $-0.624 *$ \\
\hline & & $(0.093)$ & $(0.094)$ & $(0.092)$ & $(0.113)$ & $(0.116)$ & $(0.117)$ \\
\hline \multirow{2}{*}{\multicolumn{2}{|c|}{ Separated }} & -0.156 & -0.160 & -0.157 & $-0.641 *$ & $-0.636 *$ & $-0.636 *$ \\
\hline & & $(0.167)$ & $(0.168)$ & $(0.166)$ & $(0.110)$ & $(0.112)$ & $(0.113)$ \\
\hline Widowed & & -0.116 & -0.120 & -0.124 & $-0.493 *$ & $-0.493 *$ & $-0.495 *$ \\
\hline & & $(0.073)$ & $(0.073)$ & $(0.073)$ & $(0.061)$ & $(0.060)$ & $(0.061)$ \\
\hline No. of children $\geq 8 \& 15$ vrs: & 1 & 0.031 & 0.029 & 0.026 & -0.075 & -0.078 & -0.080 \\
\hline & & $(0.025)$ & $(0.025)$ & $(0.025)$ & $(0.064)$ & $(0.064)$ & $(0.064)$ \\
\hline & 2 & 0.006 & 0.006 & 0.004 & -0.059 & -0.059 & -0.061 \\
\hline & & $(0.042)$ & $(0.041)$ & $(0.041)$ & $(0.067)$ & $(0.067)$ & $(0.066)$ \\
\hline & $>3$ & -0.163 & -0.159 & -0.159 & $-0.193^{*}$ & $-0.189 *$ & $-0.190 *$ \\
\hline & & $(0.098)$ & $(0.099)$ & $(0.099)$ & $(0.052)$ & $(0.052)$ & $(0.051)$ \\
\hline Income & & $6.6 e-5 *$ & $6.7 e-5 *$ & $4.6 e-5 *$ & $6.8 e-5 *$ & $6.9 e-5 *$ & $5.5 e-5 *$ \\
\hline & & $(3.8 \mathrm{e}-6)$ & $(3.7 e-6)$ & $(7.8 e-6)$ & $(5.9 e-6)$ & $(5.8 \mathrm{e}-6)$ & $(8.7 e-6)$ \\
\hline Top 2 Income Quartiles: & & & & $0.190 *$ & & & $0.136 *$ \\
\hline & & & & $(0.052)$ & & & $(0.062)$ \\
\hline Obs. & & 29,331 & 29,331 & 29,331 & 23,155 & 23,155 & 23,155 \\
\hline
\end{tabular}

Note: [1] Ordered logit regressions, include country and year dummies. [2] Bold-face denotes significant at the 10 percent level; Starred bold-face at the 5 per cent level. [3] Cut points in Appendix 2. The cell below the standard error (in italics) reports the predicted change in the proportion of people in the top happiness category due to a one-standard deviation change in the corresponding explanatory variable (see text for more detail). 
Table 3-Eur: Happiness Across 12 European Nations,1975-92, Poor and Rich.

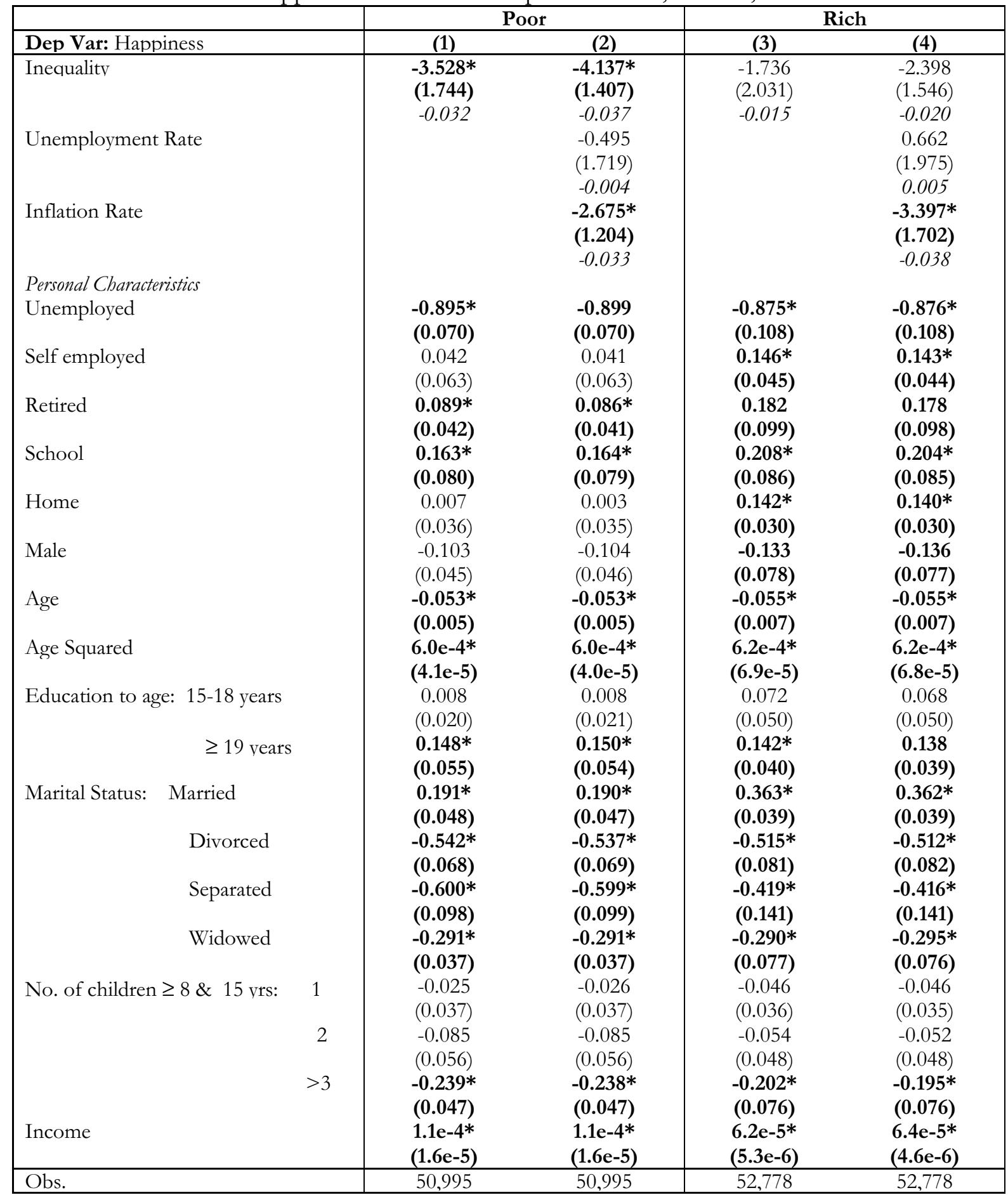

Note: [1] Ordered logit regressions, include country and year dummies. [2] Bold-face denotes significant at the 10 percent level; Starred bold-face at the 5 per cent level. [3] Cut points in Appendix 2. The cell below the standard error (in italics) reports the predicted change in the proportion of people in the top happiness category due to a one-standard deviation change in the corresponding explanatory variable (see text for more detail). 
Table 4: Comparing the Effect of Inequality across the US and Europe, 1981-96.

\begin{tabular}{|l|c|cc|cc|}
\hline \hline US & All & Left & Right & Poor & Rich \\
\hline Dep Var: Happiness & $\mathbf{( 1 )}$ & $\mathbf{( 2 )}$ & $\mathbf{( 3 )}$ & $\mathbf{( 4 )}$ & $\mathbf{( 5 )}$ \\
\hline Inequality & $\mathbf{- 0 . 0 1 4}$ & -0.009 & -0.017 & -0.008 & $\mathbf{- 0 . 0 2 0 *}$ \\
& & & & & \\
& & & & & \\
\hline Observations & 19,895 & 9,711 & 7,589 & 9,794 & 10,101 \\
\hline & & & & & Rich \\
\hline \hline Europe & All & Left & Right & Poor & $\mathbf{( 5 )}$ \\
\hline Dep Var: Happiness & $\mathbf{( 1 )}$ & $\mathbf{( 2 )}$ & $\mathbf{( 3 )}$ & $\mathbf{( 4 )}$ & -0.020 \\
\hline Inequality & & & & & \\
Different to US? & $\mathbf{- 0 . 0 2 5 *}$ & $\mathbf{- 0 . 0 3 9 *}$ & -0.013 & $\mathbf{- 0 . 0 3 7 *}$ & \\
& & & & & \\
\hline Observations. & -0.285 & -0.001 & 0.763 & -0.100 & 0.914 \\
\hline
\end{tabular}

Note: [1] Bold-face denotes significant at the 10 percent level; Starred bold-face at the 5 per cent level. [2] The numbers originate in regression (3) in Table 1, regressions (2) and (5) in Table 2, and regressions (2) and (4) in Table 3. They represent the predicted change in the proportion of people in the top happiness category due to a one-standard deviation change in inequality (see text for more detail). [3] The "Different to US?" row reports the significance level of the difference between the two inequality regression coefficients (Europe-US) obtained from a combined sample of Europeans and Americans. 


\section{Appendix 1: Description of the Data and the Surveys}

\section{Data Description}

HAPPINESS: For the US, the individual responses to the US General Social Survey question that reads "Taken all together, how would you say things are these days - would you say that you are very happy, pretty happy, or not too happy?". Accordingly, three categories were created. For Europe, the individual responses to the Eurobarometer that reads: On the whole, are you very satisfied, fairly satisfied, not very satisfied or not at all satisfied with the life you lead?". Responses falling into the two bottom categories ("not very satisfied" and "not at all satisfied") are considered to have answered the same category. Accordingly, three categories were created.

LEFT/RIGHT: In the US, we classified as "LEFT" the respondents that replied 0, 1 or 2 to the question "Generally speaking, do you usually think of yourself as a Republican, Democrat, Independent, or what?", where 0 equals "Strong Democrat", 1 equals "Not very strong Democrat" and 2 equals "Independent, close to Democrat". We classified as "right" the respondent that replied 4, 5 or 6, where 4 equals "Independent, close to Republican", 5 equals "Not very strong Republican" and 6 equals "Strong Republican".

In Europe, the classification uses a question in the Eurobarometer asking respondents "In political matters, people talk of 'the left' and 'the right'. How would you place your own views on this scale?" (from 1 to 10). Respondents were classified as being "left" if their response was in categories 1, 2, 3 or 4 and "right" if their reponse was $7,8,9$, or 10.

RICH/POOR: A respondent is classified as "rich" if he/she belongs to the top two income quartiles, and as "poor" otherwise. For the US these quartiles are based on the individual's position in his/her State in each year. For Europe the quartiles are based on the individual's position in his/her country in each year.

MURDER: The number of murders per 100,000 people for each year in each U.S. State. From "Crime in the US", various years, FBI, Washington, Government Printing Office.

INEQUALITY: For the US, Gini coefficients per state calculated from net income data, obtained by combining U.S. Current Population Survey data and tax simulations by Wu, Perloff and Golan (2002). For Europe, the Gini coefficients are obtained from the Deininger and Squire (1996) World Bank "high quality" data set.

UNEMPLOYMENT RATE: For the US, State level unemployment rates supplied by the Bureau of Labor Statistics of the US Department of Labor. For Europe, unemployment rates are obtained from the CEP OECD Data set.

INFLATION RATE: For the US, calculated from the Consumer Price Index (CPI) supplied by the Bureau of Labor Statistics of the US Department of Labor. For Europe, the inflation rate is measured by the rate of change in the CPI from the CEP OECD Data Set.

INCOME: For the United States, calculated as real income in 1995 constant dollars. Nominal income data are taken from General Social Survey questions which ask respondents where did their "total family income, from all sources, fall last year before taxes?" We take the midpoints of the corresponding categories which are, for example, "Under \$1,000; \$1,000 to 2,999; \$3,000 to 3,999; \$4,000 to 4,999; \$ 5,000 to 5,999; \$ 6,000 to 6,999; $\$ 7,000$ to 7,$999 ; \$ 8,000$ to 9,999; $\$ 10,000$ to 12,$499 ; \$ 12,500$ to 14,$999 ; \$ 15,000$ to 17,$499 ; \$ 17,500$ to 19,999 ; $\$ 20,000$ to 22,$499 ; \$ 22,500$ to 24,$999 ; \$ 25,000$ to 29,999; $\$ 30,000$ to 34,$999 ; \$ 35,000$ to 39,$999 ; \$ 40,000$ to 49,999; \$50,000 to 59,999; \$60,000 to 74,999; \$75,000 or over; Refused; Don't know; No answer". For Europe, calculated using real income in 1995 constant dollars approximated using data on individual income quartiles and the standard deviation of income. The latter is calculated as $\sigma=\log \left(Y_{90} / Y_{10}\right) / 3.28$ assuming a lognormal distribution for income where $Y_{90} / Y_{10}$ is the $90 / 10$ ratio from the Luxembourg Income Study. Using the midpoints of the four income quartiles, average income for individuals in the first, second, third and fourth quartiles equals $\log \bar{Y}-1.15 \sigma, \bar{Y}-0.32 \sigma, \bar{Y}+0.32 \sigma, \bar{Y}+1.15 \sigma$, where $\bar{Y}$ is mean income per capita. 


\section{Surveys}

\section{The United States General Social Survey (1972-1996)}

The General Social Surveys have been conducted by the National Research Center at the University of Chicago since 1972. Interviews have been undertaken during February, March and April of 1972, 1973, 1974, 1975, 1976, 1977, 1978, 1980, 1982, 1983, 1984, 1985, 1986, 1987, 1988, 1989, 1990, 1991, 1993 and 1994. There were no surveys in 1979, 1981 and 1992. There were a total of 32380 completed interviews (1613 in 1972, 1504 in 1973 , 1484 in 1974, 1490 in 1975, 1499 in 1976, 1530 in 1977, 1532 in 1978, 1468 in 1980, 1506 in 1982, 354 in the 1982 black oversample, 1599 in 1983, 1473 in 1984, 1534 in 1985, 1470 in 1986, 1466 in 1987, 353 in the 1987 black oversample, 1481 in 1988, 1537 in 1989, 1372 in 1990, 1517 in 1991, 1606 in 1993 and 2992 in 1994).

\section{The Euro-Barometer Survey Series [1975-1992]}

The Euro-Barometer Surveys used in this paper were conducted by various research firms operated within the European Community (E.C.) countries under the direction of the European Commission. Either a nationwide multi-stage probability sample or a nationwide stratified quota sample of persons aged 15 and over was selected in each of the E.C. countries. The cumulative data file used contains 36 attitudinal, 21 demographic and 10 analysis variables selected from the European Communities Studies, 1970-1973, and Euro-Barometers, 3-38.

Data for Belgium, Denmark, France, Germany, Ireland, Italy, Luxembourg, Netherlands and the United Kingdom were available for the full sample period which was used (1976-1990) whereas data were only available from 1981 to 1990 for Greece and from 1985 to 1990 for both Spain and Portugal. The number of observations in our sample was 4993 for Belgium, 24764 for Britain, 4054 for Denmark, 4346 for France, 5708 for West Germany, 2652 for Greece, 1812 for Ireland, 24189 for Italy, 494 for Luxembourg, 20255 for The Netherlands, 2380 for Portugal and 8126 for Spain.

\section{Appendix 2: Cut Points}

Table 1-US: Cut points (standard errors) are -2.76 (0.14), 0.3 (0.15) for reg. (1); -3.83 (0.49), -0.77 (0.50) for reg. (2); -3.71 (0.47), -0.64 (0.48) for reg. (3); -3.70 (0.47), -0.63 (0.48) for reg. (4).

Table 2-US: Cut points (standard errors) are $-3.3(0.5), 0.3$ (0.5) for reg. (1); -3.16 (0.47), -0.13 (0.47) for reg. (2); -3.15 (0.47), -0.12 (0.47) for reg. (3); $-3.70(0.47),-0.63$ (0.48) for reg. (4); -4.09 (0.74), $-0.89(0.74)$ for reg. (5); $-4.10(0.74),-0.89$ (0.74) for reg. (6).

Table 3-US: Cut points (standard errors) are -3.44 (0.7), -0.5 (0.71) for reg. (1); -3.24 (0.68), -0.29 (0.69) for reg. (2); -4.25 (0.54), -0.95 (0.54) for reg. (3); -4.24 (0.53), -0.96 (0.53) for reg. (4).

Table 4-US: Cut points (standard errors) are -3.80 (0.45), -0.73 (0.46) for reg. (1); -3.40 (0.51), -0.36 (0.51) for reg. (2); 4.17 (0.78), -0.96 (0.78) for reg. (3); -3.26 (0.69), -0.31 (0.69) for reg. (4); -4.23 (0.60), -0.94 (0.61) for reg. (5).

Table 1-Eur: Cut points (standard errors) are -0.86 (0.20), 1.95 (0.19) for reg. (1); -1.92 (0.82), 0.89 (0.82) for reg. (2); -2.23 (0.70), 0.58 (0.68) for reg. (3); -2.36 (0.71), 0.45 (0.69) for reg. (4).

Table 2-Eur: Cut points (standard errors) are -3.3 (0.49), -0.48 (0.43) for reg. (1); -2.85 (0.59), -0.03 (0.51) for reg. (2); -3.05 (0.61), -0.23 (0.54) for reg. (3); -1.47 (0.9), -0.10 (0.69) for reg. (4); -1.54 (0.96), 1.28 (0.98) for reg. (5); -1.63 (0.99), 1.19 (1.0) for reg. (6).

Table 3-Eur: Cut points (standard errors) are -1.96 (0.79), 0.68 (0.77) for reg. (1); -2.31 (0.70), 0.33 (0.68) for reg. (2); -1.67 (0.92), 1.33 (0.92) for reg. (3); -1.89 (0.73), 1.12 (0.70) for reg. (4). 
Table 4-US: The Determinants of Happiness in the US, 1981-96, with crime.

\begin{tabular}{|c|c|c|c|c|c|}
\hline \multirow{2}{*}{ Dep Var: Happiness } & All & Left & Right & Poor & Rich \\
\hline & (1) & $(2)$ & (3) & $(4)$ & $(5)$ \\
\hline Inequality & -2.077 & $\begin{array}{l}-1.345 \\
(1.108)\end{array}$ & -2.282 & -1.268 & $-2.776^{*}$ \\
\hline \multirow{2}{*}{ Unemployment Rate } & -2.516 & $-3.170 *$ & -2.608 & $-4.730 *$ & -0.281 \\
\hline & $(1.472)$ & (1.617) & $(2.888)$ & (1.957) & $(1.824)$ \\
\hline \multirow[t]{2}{*}{ Murder } & -0.009 & -0.016 & -0.007 & -0.023 & 0.002 \\
\hline & $(0.156)$ & $(0.018)$ & $(0.027)$ & $(0.017)$ & $(0.021)$ \\
\hline \multirow[t]{2}{*}{ Auto-Theft } & $1.4 \mathrm{e}-5$ & $-9.6 e-5$ & $2.1 \mathrm{e}-4$ & $8.5 e-5$ & $-2.3 e-4$ \\
\hline & $(1.6 e-4)$ & $(2.2 \mathrm{e}-4)$ & $(2.5 e-4)$ & $(2.6 \mathrm{e}-4)$ & $(1.9 \mathrm{e}-4)$ \\
\hline \multicolumn{6}{|l|}{ Personal Characteristics } \\
\hline \multirow[t]{2}{*}{ Unemployed } & $-0.623 *$ & $-0.476 *$ & $-0.691 *$ & $-0.594 *$ & $-0.576 *$ \\
\hline & $(0.105)$ & $(0.138)$ & $(0.227)$ & $(0.111)$ & $(0.213)$ \\
\hline \multirow[t]{2}{*}{ Self employed } & 0.055 & $-4.0 e-4$ & $0.157^{*}$ & -0.063 & $0.153^{*}$ \\
\hline & $(0.039)$ & $(0.067)$ & $(0.063)$ & $(0.075)$ & $(0.050)$ \\
\hline \multirow[t]{2}{*}{ Retired } & 0.021 & -0.032 & 0.070 & -0.061 & 0.131 \\
\hline & $(0.056)$ & $(0.071)$ & $(0.103)$ & $(0.075)$ & $(0.119)$ \\
\hline \multirow[t]{2}{*}{ School } & 0.224 & 0.116 & $0.367^{*}$ & $0.386^{*}$ & $0.377^{*}$ \\
\hline & $(0.135)$ & $(0.162)$ & $(0.168)$ & $(0.145)$ & $(0.154)$ \\
\hline \multirow[t]{2}{*}{ Home } & -0.030 & -0.061 & 0.091 & $-0.132 *$ & $0.178^{*}$ \\
\hline & $(0.048)$ & $(0.056)$ & $(0.099)$ & $(0.060)$ & (0.077) \\
\hline \multirow[t]{2}{*}{ Other } & $-0.547 *$ & $-0.604 *$ & $-0.643 *$ & $-0.742 *$ & $0.458 *$ \\
\hline & $(0.107)$ & $(0.201)$ & $(0.283)$ & $(0.130)$ & $(0.212)$ \\
\hline \multirow[t]{2}{*}{ Male } & $-0.164 *$ & $-0.133 *$ & $-0.256^{*}$ & $-0.232 *$ & $-0.105^{*}$ \\
\hline & $(0.030)$ & $(0.040)$ & $(0.049)$ & $(0.051)$ & $(0.034)$ \\
\hline \multirow[t]{2}{*}{ Age } & $-0.038 *$ & $-0.028 *$ & $-0.041 *$ & $-0.034 *$ & $-0.049 *$ \\
\hline & $(0.007)$ & $(0.009)$ & $(0.010)$ & $(0.008)$ & $(0.010)$ \\
\hline \multirow[t]{2}{*}{ Age Squared } & $4.8 \mathrm{e}-4^{*}$ & $4.0 \mathrm{e}-4^{*}$ & $4.9 \mathrm{e}-4^{*}$ & $4.5 \mathrm{e}-4^{*}$ & $5.9 \mathrm{e}-4 *$ \\
\hline & $(7.5 e-5)$ & $(9.3 e-5)$ & $(1.1 \mathrm{e}-5)$ & $(8.0 \mathrm{e}-5)$ & $(1.2 \mathrm{e}-4)$ \\
\hline \multirow[t]{2}{*}{ Education: College } & $0.143^{\prime \prime}$ & $0.112 *$ & $0.140 *$ & $0.146 *$ & $0.111 *$ \\
\hline & $(0.031)$ & $(0.051)$ & $(0.062)$ & $(0.045)$ & (0.047) \\
\hline \multirow[t]{2}{*}{ Graduate } & $0.173^{*}$ & $0.198 *$ & $0.183^{*}$ & $0.249 *$ & $0.136^{*}$ \\
\hline & $(0.056)$ & $(0.086)$ & (0.079) & $(0.121)$ & $(0.061)$ \\
\hline \multirow[t]{2}{*}{ Marital Status: Married } & $0.620 *$ & $0.482 *$ & $0.611^{*}$ & $0.622 *$ & $0.608 *$ \\
\hline & (0.049) & $(0.064)$ & $(0.084)$ & $(0.078)$ & (0.059) \\
\hline \multirow[t]{2}{*}{ Divorced } & $-0.176^{*}$ & $-0.295 *$ & $-0.215 *$ & $-0.220 *$ & -0.047 \\
\hline & $(0.073)$ & $(0.094)$ & $(0.079)$ & $(0.074)$ & $(0.108)$ \\
\hline \multirow[t]{2}{*}{ Separated } & $-0.487 *$ & $-0.488 *$ & $-0.768 *$ & $-0.407^{*}$ & $-0.614 *$ \\
\hline & $(0.105)$ & $(0.130)$ & $(0.174)$ & $(0.122)$ & $(0.200)$ \\
\hline Widowed & $-0.349 *$ & $-0.380 *$ & $-0.474 *$ & $-0.313^{*}$ & -0.250 \\
\hline & $(0.078)$ & $(0.090)$ & $(0.114)$ & $(0.081)$ & $(0.142)$ \\
\hline No. of children: & $-0.182 *$ & $-0.173^{*}$ & $-0.162 *$ & $-0.228 *$ & $-0.144 *$ \\
\hline & $(0.035)$ & $(0.050)$ & $(0.075)$ & $(0.057)$ & $(0.058)$ \\
\hline 2 & $-0.138^{*}$ & -0.123 & -0.046 & $-0.277^{*}$ & -0.015 \\
\hline & $(0.044)$ & $(0.074)$ & $(0.073)$ & $(0.080)$ & $(0.646)$ \\
\hline$>3$ & $-0.161 *$ & $-0.130 *$ & -0.081 & $-0.191 *$ & -0.121 \\
\hline & $(0.049)$ & $(0.060)$ & $(0.062)$ & $(0.062)$ & $(0.074)$ \\
\hline Income & $8.3 e-6^{*}$ & $8.6 e-6^{*}$ & $7.2 \mathrm{e}-6^{*}$ & $2.3 e-5 *$ & $7.1 \mathrm{e}-6^{*}$ \\
\hline & $(9.7 e-7)$ & $(1.9 \mathrm{e}-6)$ & $(1.3 e-6)$ & $(3.5 e-6)$ & $(8.9 \mathrm{e}-7)$ \\
\hline Top 2 Income Quartiles: & $0.116^{*}$ & 0.091 & 0.148 & & \\
\hline & $(0.056)$ & $(0.081)$ & $(0.078)$ & & \\
\hline Black & $-0.393 *$ & $-0.319 *$ & $-0.503 *$ & $-0.267 *$ & $-0.536 *$ \\
\hline & $(0.048)$ & $(0.050)$ & $(0.176)$ & $(0.068)$ & $(0.060)$ \\
\hline Obs. & 19,895 & 9,711 & 7,589 & 9,794 & 10,101 \\
\hline
\end{tabular}

Note: [1] Ordered logit regressions, include State and year dummies. [2] Bold-face denotes significant at the 10 percent level; Starred bold-face at the 5 per cent level. [3] Cut points in Appendix 2. 